\title{
Chitosan gold nanoparticles induce cell death in HeLa and MCF-7 cells through reactive oxygen species production
}

This article was published in the following Dove Press journal: International Journal of Nanomedicine

\section{Ana Carolina Martínez- Torres \\ Diana G Zarate-Triviño Helen Yarimet Lorenzo- Anota \\ Andrea Ávila-Ávila Carolina Rodríguez-Abrego Cristina Rodríguez-Padilla}

Laboratory of Immunology and Virology, Faculty of Biological Sciences, Autonomous University of Nuevo Leon, Monterrey, Mexico
Correspondence: Ana Carolina MartínezTorres

Laboratorio de Inmunología y Virología, Facultad de Ciencias Biológicas, Universidad Autónoma de Nuevo León, Monterrey 66455, México

Tel +5281214115

Fax +528183524212

Email ana.martinezto@uanl.edu.mx
Background: Nanotechnology has gained important interest, especially in the development of new therapies; the application of gold nanoparticles (AuNPs) in the treatment and detection of diseases is a growing trend in this field. As cancer represents a serious health problem around the world, AuNPs are studied as potential drugs or drug carriers for anticancer agents. Recent studies show that AuNPs stabilized with chitosan $(\mathrm{CH})$ possess interesting biological activities, including potential antitumor effects that could be selective to cancer cells.

Materials and methods: In this study, we synthesized sodium citrate-AuNPs and $\mathrm{CH}-$ capped AuNPs of 3-10 nm, and analyzed their cytotoxicity in cervical (HeLa) and breast (MCF-7) cancer cells, and in peripheral blood mononuclear cells (PBMCs). Then, we evaluated the clonogenic potential, cell cycle, nuclear alterations, caspase dependence, and reactive oxygen species (ROS) production in HeLa and MCF-7 cells after chitosan gold nanoparticles (CH-AuNPs) exposure.

Results: Our data showed that $\mathrm{CH}$-AuNPs are cytotoxic in a dose-dependent manner in the cancer cell lines tested, while they induce low cytotoxicity in PBMCs. Sodium citrate gold nanoparticles did not show cytotoxic effects. In both HeLa and MCF-7 cell lines, CH-AuNPs inhibit clonogenic potential without inducing cell cycle arrest or nuclear alterations. The cell death mechanism is specific for the type of cancer cell line tested, as it depends on caspase activation in HeLa cells, whereas it is caspase independent in MCF-7 cells. In all cases, ROS production is mandatory for cell death induction by $\mathrm{CH}-\mathrm{AuNPs}$, as ROS inhibition with N-acetyl cysteine inhibits cell death.

Conclusion: Our results show that $\mathrm{CH}-\mathrm{AuNPs}$ are selective for HeLa and MCF-7 cancer cells, rather than normal PBMCs, and that ROS production seems to be a conserved feature of the cell death mechanism induced by $\mathrm{CH}$-AuNPs. These results improve the knowledge of $\mathrm{CH}$-AuNPs and open the way to the design of new pharmacological strategies using these agents against cancer.

Keywords: AuNPs, cancer, PBMC, nuclear alterations, cell cycle, ROS

\section{Introduction}

Nanotechnology research has increased in many different areas in the last years, including biomedicine, where nanoparticles have been assessed by their potential to be used against different diseases like cancer. Nanoparticles have been shown to be interesting options in cancer diagnostics and therapeutics, ${ }^{1-3}$ as an alternative to nonviral delivery systems. ${ }^{4}$ Among the different types of nanoparticles, gold nanoparticles (AuNPs) have been demonstrated to inhibit proliferation and induce cell death on different types of cancer cell lines: ${ }^{1-3,5-7}$ moreover, they have been shown to be safe in several 
biological models, and interesting agents for drug delivery and photothermal therapy against cancer. ${ }^{8}$

Cervical cancer and breast cancer are among the leading causes of mortality in women around the world. ${ }^{9}$ These cancers have several mutations that make cells proliferate continuously and evade regulated cell death (RCD), a mechanism by which the cell activates its own machinery to self-destruct. ${ }^{10}$ The first-line therapies for breast and cervical cancers consist of surgery, immunotherapy, polyamine synthesis inhibitors, individual micronutrient supplementation, hormonal therapy, chemotherapy, and radiotherapy; however, these treatments also cause many side effects. Moreover, it is known that mutations or deletions in proteins related to apoptosis induce resistance to conventional treatments. ${ }^{11}$ These are the reasons why nanotechnology shows great promise for the improvement of traditional cancer treatments.

It has been observed that the efficacy and effect of nanoparticles on cancer and healthy cells are determined by several conditions of synthesis such as size, shape, and, especially, the reducing agent used. ${ }^{12,13}$ We propose the use of AuNPs stabilized with chitosan (chitosan gold nanoparticles [CH-AuNPs]), a polycationic natural polymer shown to be biocompatible, biodegradable, and cytotoxic to cancer cells. ${ }^{14,15}$ The synthesis of AuNPs coated with chitosan is an interesting approach, as it confers a positive charge to AuNPs, thus increasing their affinity with the negative charge of the cell membrane. ${ }^{16,17}$ This is the reason why the use of chitosan in the design of agents for drug delivery has increased over the last years, and its association with nanostructures is of great importance. ${ }^{15}$ Many investigations have determined that the cytotoxicity of nanoparticles depends on their physicochemical properties. ${ }^{18-20}$ These properties give a variety of effects that depend on the kind of cancer and healthy cells analyzed. ${ }^{20}$ For this reason, it is essential to study the particular characteristics of the nanoparticles and to evaluate them in different types of cells. Few reports have described the biological effects of $\mathrm{CH}$-AuNPs in cancer cells, ${ }^{5,17}$ and there is no description of their effect in primary healthy cells. Additionally, their mechanism of action in cancer cells is poorly understood.

Thus, the purpose of this study was to analyze the cytotoxicity of AuNPs in cervical (HeLa) and breast (MCF-7) cancer cell lines, and in peripheral blood mononuclear cells (PBMCs) using chitosan $(\mathrm{CH})$ and sodium citrate (SC, our control) as reducing agents. We further characterized the mechanism of cytotoxicity of CH-AuNPs in cancer cells, as we assessed the clonogenic potential, cell cycle, DNA alterations, caspase dependence, and reactive oxygen species (ROS) production after treatment with $\mathrm{CH}-\mathrm{AuNPs}$.

\section{Materials and methods Nanoparticle synthesis}

$\mathrm{CH}$-AuNPs and sodium citrate gold nanoparticles (SC-AuNPs) were synthesized using the Turkevich method, with adaptations of the protocol described by Arvizo et al. ${ }^{18}$ In brief, an acid solution of chitosan $(2 \% \mathrm{w} / \mathrm{w}$ in acetic acid $0.4 \mathrm{M})$ was obtained by dissolving chitosan (medium molecular weight, $300,000 \mathrm{~g} / \mathrm{mol}$, with $75 \%-85 \%$ of deacetylation) in $2 \mathrm{mM}$ hydrochloroauric acid solution $\left(\mathrm{HAuCl}_{4}\right)$, and it was homogenized at room temperature for 15 minutes on a magnetic plate at $80-90 \mathrm{rpm}$. The resulting solution was heated $\left(100^{\circ} \mathrm{C} \pm 5^{\circ} \mathrm{C}\right.$ in glycerol bath for 15 minutes on a magnetic plate at $80-90 \mathrm{rpm}$ ) until it changed color to wine red. SC-AuNPs were obtained by heating $\mathrm{HAuCl}_{4}(2 \mathrm{mM})$ at $140^{\circ} \mathrm{C}\left( \pm 5^{\circ} \mathrm{C}\right)$ in a glycerol bath for 5 minutes on a magnetic plate at $80-90 \mathrm{rpm}$, and then $1 \%$ sodium citrate solution (Milliporesigma, St Louis, MO, USA) was added by slow drip until it changed color to wine red.

\section{Nanoparticle characterization}

Mean particle diameter and $\mathrm{Z}$ potential were measured by dynamic light scattering (DLS) using Nanosizer NS90 (Siemens, Malvern, PA, USA). The sample was dispersed in distilled water $(1: 1,000)$. The surface plasmon resonance was detected by Ultra visible spectroscopy using a Nanodrop spectrophotometer 2000c (Thermo Fisher Scientific, Bartlesville, OK, USA). The morphology of the particles was observed with field emission scanning electron microscopy (SEM, Nova NanoSEM200; FEI, Hillsboro, OR, USA).

\section{Cell culture}

Human cervix adenocarcinoma cells, HeLa, were obtained from the American Type Culture Collection (ATCC, Manassas, VA, USA). Human breast adenocarcinoma cell line, MCF-7, was a gift from Dr J Gutierrez-Uribe (Nutriomics group, ITESM) who obtained the cell line from ATCC; this was approved by the Institutional Ethics Committee at the Universidad Autónoma de Nuevo León, College of Biological Sciences.

Peripheral blood was collected from six volunteers not showing an apparent disease (men and women, with age ranging 18-30 years) after obtaining written informed consent. This study was approved by the Institutional Ethics Committee at the Universidad Autónoma de Nuevo León, College of Biological Sciences. PBMCs were obtained through density centrifugation with Ficoll-Hypaque-1119 (Milliporesigma). HeLa and MCF-7 cells were cultured in DMEM-F12 while PBMCs were cultured in Roswell Park Memorial Institute (RPMI) 1640 (Gibco, Grand Island, NY, USA). Both the 
culture media were supplemented with $10 \%$ fetal bovine serum (Gibco) and 1\% penicillin-streptomycin (Gibco) and were maintained in a humidified incubator containing 5\% $\mathrm{CO}_{2}$ at $37^{\circ} \mathrm{C}$. Cells were routinely grown in plastic tissueculture dishes (Corning, NY, USA).

\section{Cell viability assessment}

Cell growth inhibition was determined by MTT dye absorbance by living cells; this assay consists in measurement and quantified spectrophotometric means of reduction of yellow tetrazolium (3- (4, 5-dimethylthiazilyl-1) -2, 5- diphenyl tetrazolium bromide) (Milliporesigma) by metabolically active cells in intracellular purple formazan. In brief, $5 \times 10^{3}$ cells per well were seeded in 96-well microtiter plates (Corning) for MTT assays. After exposure to CH-AuNPs, SC-AuNPs, chitosan, and $\mathrm{HACl}_{4}$ at different concentrations $(25,50,75,100$, and $150 \mu \mathrm{M})$ for 24 hours, $20 \mu \mathrm{L}$ of MTT solution $(2 \mathrm{mg} / \mathrm{mL}$ in phosphate-buffered saline [PBS]) was added to each well. The concentrations of CH-AuNPs and SC-AuNPs $(\mu \mathrm{M})$ were determined based on the $\mu \mathrm{M}$ concentration of the precursor salt $\left(\mathrm{HACl}_{4}\right)$ used for the synthesis of AuNPs. The plates were incubated for three additional hours at $37^{\circ} \mathrm{C}$, after which the MTT solution in the medium was aspirated and $200 \mu \mathrm{L}$ of dimethyl sulfoxide (DMSO) (Milliporesigma) was added to each well to solubilize the formazan crystals formed in the viable cells. The optical density was measured at $570 \mathrm{~nm}$ using a microplate reader (Synergy2, Biotek, Winooski, VT, USA).

\section{Cell death analysis}

Cell death was determined by staining cells with Annexin V-allophycocyanin (APC) (AnnV, $0.1 \mu \mathrm{g} / \mathrm{mL}$; BD Biosciences Pharmingen, San Jose, CA, USA) and propidium iodide (PI; $0.5 \mu \mathrm{g} / \mathrm{mL}$; Milliporesigma). $4 \times 10^{4}$ cells were seeded in 24-well plates (Corning) and were incubated at different concentrations of CH-AuNPs $(50,75$, and $100 \mu \mathrm{M})$ for 24 hours to find the median cytotoxic concentration of $\mathrm{CH}-\mathrm{AuNPs}$ required to reduce cell viability by $50 \%\left(\mathrm{CC}_{50}\right)$. After 24 hours, the cells were detached and washed twice with PBS and then resuspended in $200 \mu \mathrm{L}$ of binding buffer (10 mM HEPES/NaOH pH 7.4, 140 mM NaCl, $2.5 \mathrm{mM}$ $\left.\mathrm{CaCl}_{2}\right)$ containing AnnV $(0.1 \mu \mathrm{g} / \mathrm{mL})$ and PI $(0.5 \mu \mathrm{g} / \mathrm{mL})$. Cells were then assessed with flow cytometer (BDAccury6; Becton Dickinson, San Jose, CA, USA) and analyzed using FlowJo Software (Tree Star Inc., Ashland, OR, USA).

\section{Cell death induction and inhibition}

Etoposide (Enzo, Farmingdale, NY, USA), and QVD (BioVision, Milpitas, CA, USA) were dissolved in DMSO.
N-acetyl-L-cysteine (NAC; Sigma, Shanghai, China) was dissolved in MilliQ water. For cell death inhibition, we used QVD, a caspase inhibitor. To determine ROS-dependent cell death, we used NAC as an ROS inhibitor. QVD and NAC were added 30 minutes before treatment with $\mathrm{CH}$ AuNPs. All stock solutions were wrapped in foil and stored at $-20^{\circ} \mathrm{C}$.

\section{Clonogenic assay}

Cell proliferation and clonogenicity were assessed using the clonogenic assay technique. In brief, 100 or 500 cells were plated in 6-well plates for control (only cell culture media) or CH-AuNPs treatment, respectively, and were incubated overnight. Once attached, cells were exposed to either treatment or control for 24 hours. Afterward, the medium was changed and cells were allowed to grow until colony formation (10 days). Then, the colonies were fixed with methanol (100\%) and glacial acetic acid (3:1), stained with $0.5 \%$ Gentian Violet. Colonies with $>50$ cells were counted manually. Finally, cell survival was determined by equating the number of colonies in treated wells over those in control, both normalized with the percentage of cell colonies counted over the number of cells seeded.

\section{Cell cycle analysis}

Cell cycle distributions were determined by PI staining. In brief, $5 \times 10^{5}$ cells in 6 -well dishes were incubated with concentration required to reduce cell viability by $25 \%\left(\mathrm{CC}_{25}\right), \mathrm{CC}_{50}$, and concentration required to reduce cell viability by $75 \%$ $\left(\mathrm{CC}_{75}\right)$ of $\mathrm{CH}$-AuNPs for 24 hours. Cells were then washed with PBS and fixed in 70\% ethanol. Cells were washed again with PBS, then incubated with PI $(10 \mu \mathrm{g} / \mathrm{mL})$ with simultaneous RNase treatment at $37^{\circ} \mathrm{C}$ for 30 minutes. Cell DNA contents were measured using a flow cytometer (Becton Dickinson) and analyzed using FlowJo Software. For DNA degradation, we analyzed the SubG1 population obtained from cell cycle analysis using a flow cytometer (BDAccury6; Becton Dickinson) and FlowJo Software (Tree Star Inc.).

\section{Nuclear assessment}

For chromatin condensation after $\mathrm{CH}$-AuNPs treatment we did Hoechst staining (Enzo). In brief, $10 \times 10^{5}$ cells were incubated in 6-well plates, then treated with $\mathrm{CH}-\mathrm{AuNPs} \mathrm{CC}_{50}$, and then washed in PBS and fixed with paraformaldehyde 4\%. We stained the cells for 5 minutes using $5 \mu \mathrm{g} / \mathrm{mL}$ Hoechst 33342. Cells were then washed with PBS, observed using a fluorescence microscope (OLYMPUS IX70), and analyzed with Image-J software. 


\section{Caspase analysis}

Caspase activity was measured using Caspase 3 (active) FITC staining kit (ABCAM, Eugene, OR, USA). In brief, $5 \times 10^{5}$ cells in 6-well dishes (Corning) were incubated with $\mathrm{CH}$-AuNPs $\mathrm{CC}_{50}$. Cells were then recovered and stained following the manufacturer's instructions. Caspase activity was measured using a flow cytometer (BDAccury6; Becton Dickinson) and analyzed using FlowJo Software (Tree Star Inc.).

\section{ROS production assay}

ROS generation was measured using $2.5 \mu \mathrm{M}$ of dichlorodihydrofluorescein diacetate (DCFDA; Invitrogen, St Louis, MO, USA). In brief, $5 \times 10^{5}$ cells were incubated in 6-well dishes (Corning) with the indicated concentration of $\mathrm{CH}-\mathrm{AuNPs}$. Cells were then recovered, washed with PBS, stained, incubated at $37^{\circ} \mathrm{C}$ for 30 minutes, and measured using a flow cytometer (Becton Dickinson, BDAccury6), and analyzed using FlowJo Software (Tree Star Inc.).

\section{Statistical analysis}

The results given in this study represent the mean of at least three independent experiments done in triplicate (mean \pm SD). The data were analyzed using GraphPad Prism (GraphPad Software, San Diego, CA, USA). Statistical analysis was done using paired Student's $t$-test. The statistical significance was defined as $p<0.05$.

\section{Results}

\section{Nanoparticles}

$\mathrm{CH}$-AuNPs have a $\mathrm{Z}$ potential of $+27 \mathrm{mV}$ upon synthesis, while control SC-AuNPs showed a $\mathrm{Z}$ potential of $-5 \mathrm{mV}$ (Table 1). Both types of AuNPs have a size range of 3-10 nm (Table 1; Figure 1A). The polydispersity of SCAuNPs and CH-AuNPs was 0.3 (Table 1), and they show a typical surface plasmon resonance of $\mathrm{AuNPs}^{22}$ at $520 \mathrm{~nm}$ (Table 1; Figure 1B). We confirmed the size and shape of the CH-AuNPs by SEM (Figure 1C). Table 1 shows the comparative physicochemical properties of $\mathrm{CH}$-AuNPs and SC-AuNPs.

\section{$\mathrm{CH}-A u N P s$ but not SC-AuNPs diminish cell viability in cancer cells}

$\mathrm{CH}-\mathrm{AuNPs}$ have been shown to suppress cell viability in lung adenocarcinoma cell lines (A549, NCI-H460, and A431) and acute monocytic leukemia cell line (THP-1). ${ }^{5,17,23}$ However, there are no reports regarding its cytotoxic effect on cervical cancer and breast cancer cells, and on primary PBMC. Thus, we determined the effect of SC-AuNPs, CH-AuNPs, and the vehicles used to synthesize CH-AuNPs (chitosan and $\mathrm{HAuCl}_{4}$ ) on HeLa and MCF-7 cancer cell lines, and PBMC. CH-AuNPs induced a concentration-dependent cell viability diminution in cancer cells, whereas SC-AuNPs did not induce an important cell viability loss (Figure 2A and B). The $\mathrm{CC}_{50}$ of CH-AuNPs for HeLa and MCF-7 cells after 24 hours of treatment was $75 \mu \mathrm{M}$, which increased with the concentration, reaching $85 \%$ and $100 \%$ of cell viability loss, respectively, at $150 \mu \mathrm{M}$ (Figure $2 \mathrm{~A}$ and B). We observed a clear selectivity for cancer cells, because cell viability diminution in PBMCs was observed when the concentration reached $75 \mu \mathrm{M}$, attaining $40 \%$ of cell viability loss when using the highest concentration tested $(150 \mu \mathrm{M}$, Figure 2C). Additionally, although $\mathrm{CH}-\mathrm{AuNPs}$ showed more cytotoxicity in HeLa and MCF-7 cell lines after 48 hours of treatment, $\mathrm{PBMC}$ showed the same sensitivity for $\mathrm{CH}-\mathrm{AuNPs}$ (Figure $\mathrm{S} 1$ ). Furthermore, neither chitosan nor $\mathrm{HAuCl}_{4}$ alone induces high cytotoxicity in any of the cell type assessed (Figure 2D-F).

\section{Chitosan-capped gold nanoparticles induce cell death in cancer cells}

Because SC-AuNPs were not effective against cancer cells at the same doses as $\mathrm{CH}$-AuNPs, we continued to evaluate whether cell death was induced by CH-AuNPs in HeLa, MCF-7, and PBMC. We evaluated cell death by assessing phosphatidylserine (PS) exposure (AnnV) and membrane

Table I Overview of the gold nanoparticles used in this study

\begin{tabular}{|c|c|c|c|c|c|c|c|}
\hline Sample & Surface coating & $\begin{array}{l}\text { Zeta potential } \\
(\mathrm{mV}) \pm \mathrm{SD}\end{array}$ & $\begin{array}{l}\text { Range size } \\
(\mathrm{nm})\end{array}$ & $\begin{array}{l}\text { Mean size } \\
\pm \text { SD (nm) }\end{array}$ & Polydispersity & Solvent & $\begin{array}{l}\text { Surface plasmon } \\
\text { resonance }(\mathrm{nm})\end{array}$ \\
\hline SC-AuNPs & Sodium citrate $0.1 \%$ & $-5 \pm 0.1$ & $3-10$ & $3 \pm 0.5$ & 0.3 & Water & 520 \\
\hline $\mathrm{CH}$-AuNPs & Chitosan $0.2 \%$ & $+27 \pm 0.1$ & $3-10$ & $4 \pm 0.6$ & 0.3 & Water & 520 \\
\hline SC-AuNPs & Sodium citrate $0.1 \%$ & $-7 \pm 0.2$ & $3-10$ & $3 \pm 0.6$ & 0.2 & PBS & 522 \\
\hline $\mathrm{CH}-\mathrm{AuNPs}$ & Chitosan $0.2 \%$ & $+22 \pm 0.2$ & $3-10$ & $4 \pm 0.5$ & 0.2 & PBS & 522 \\
\hline
\end{tabular}

Notes: Size, Z potential, and surface plasmon resonance of AuNPs were measured as stated in the "Materials and methods" section. AuNPs were diluted in water or PBS before the assessment of their physicochemical properties.

Abbreviations: CH-AuNPs, chitosan gold nanoparticles; PBS, phosphate buffered saline; SC-AuNPs, sodium citrate gold nanoparticles. 

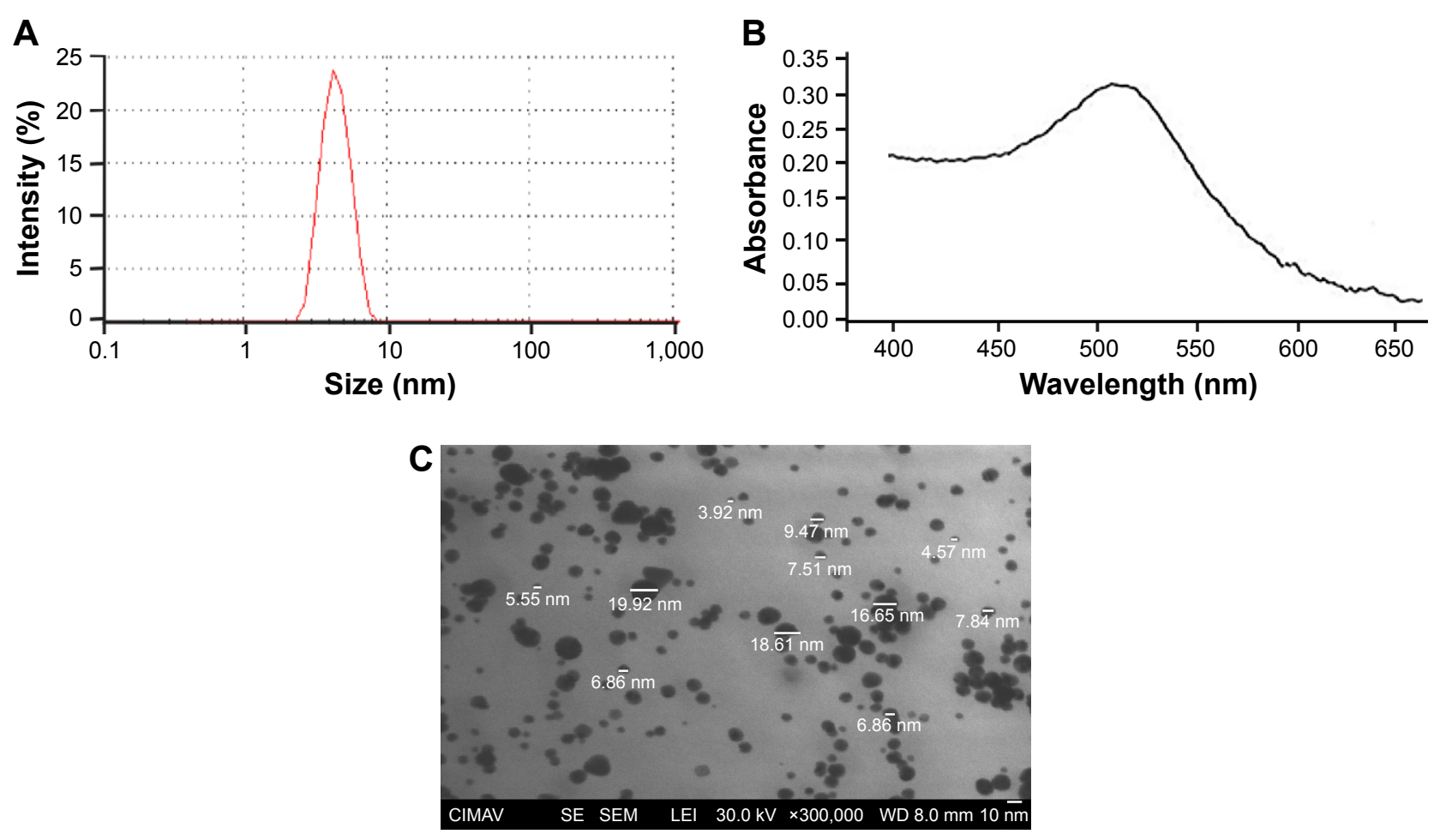

Figure I Size, surface plasmon resonance, and shape of $\mathrm{CH}$-AuNPs.

Note: Representative (A) size distribution obtained from DLS analysis, (B) UV-Vis absorption spectrum, and (C) SEM images of CH-AuNPs.

Abbreviations: $\mathrm{CH}-\mathrm{AuNPs}$, chitosan gold nanoparticles; DLS, dynamic light scattering; SEM, scanning electronic microscopy; CIMAV, Centro de Investigación en Materiales Avanzados S.C.; SE, secondary electron; LEI, lower detector; WD, working distance.

permeability (PI) after 24 hours of treatment with different concentrations of CH-AuNPs (Figure 3). PS exposure on the outer leaflet of the plasma membrane is an "eat-me" signal of dying cells. ${ }^{24}$ In HeLa and MCF-7 cells, CH-AuNPs induced a small population of AnnV and PI-positive cells at a concentration of $50 \mu \mathrm{M}$; at $75 \mu \mathrm{M}$ this percentage increased, and at $100 \mu \mathrm{M}$ most of the cells were double positive to AnnV and PI staining (Figure 3A). On the other hand, at the three concentrations tested, they induced only a slight population of AnnV and PI-positive PBMC (Figure 3A). Contrary to the results obtained with the use of etoposide, where we observed resistance to cell death in MCF-7 cells and no selectivity for PBMCs (Figure S2), with CH-AuNPs we observed $<15 \%$ of cell death in PBMC at the $\mathrm{CC}_{50}$ of MCF-7 and HeLa cells, and $<20 \%$ at their $\mathrm{CC}_{75}$ (Figure 3B). As expected from the MTT results, $\mathrm{CH}-\mathrm{AuNPs}$ induced cell death in a concentration-dependent manner, and cell death in cancer cells was detected at the same doses observed in MTT (Figure 3).

\section{$\mathrm{CH}$-AuNPs inhibit long-term proliferation of cancer cells}

Once we assessed that PBMCs were only slightly affected by $\mathrm{CH}-\mathrm{AuNPs}$, we focused on deciphering the cytotoxic mechanism of CH-AuNPs in cancer cells. First, we assessed if MCF-7 and HeLa cells could recover after 24 hours of treatment with $\mathrm{CH}-\mathrm{AuNPs}$. The cells were treated for 24 hours with the $\mathrm{CC}_{25}$ and $\mathrm{CC}_{50}$ of $\mathrm{CH}-\mathrm{AuNPs}$ for each cancer cell line tested, then treatment was stopped and washed, and cells were cultured until colony formation. Clonogenic assay showed that $\mathrm{CH}$-AuNPs have antiproliferative activity, as they reached complete inhibition of colony formation at the $\mathrm{CC}_{25}$ of CH-AuNPs; this result was confirmed with the $\mathrm{CC}_{50}$ in $\mathrm{HeLa}$ (Figure 4A) and MCF-7 cells (Figure 4B). Thus, even if the $\mathrm{CC}_{25}$ and $\mathrm{CC}_{50}$ of $\mathrm{CH}$-AuNPs were not able to kill all of the cells, these concentrations were able to inhibit long-term cell growth, after a 24 hour exposure.

\section{$\mathrm{CH}-A u N P s$ do not modify the cell cycle of cancer cells}

It has been shown that AuNPs can induce cell cycle arrest in different cancer cells ${ }^{25}$ and that chitosan induces cell cycle arrest in G1 and S phases in oral cancer cells; $;{ }^{26}$ thus, we further assessed cell cycle after $\mathrm{CH}-\mathrm{AuNPs}$ treatment. Even though AuNPs and chitosan separately induce cell cycle arrest in several cancer cell lines, treatment with $\mathrm{CC}_{25}, \mathrm{CC}_{50}$, or $\mathrm{CC}_{75}$ of $\mathrm{CH}$-AuNPs for 24 hours does not induce changes in the cell cycle of HeLa (Figure 5A) or MCF-7 (Figure 5B) cell lines. This indicates that cell viability diminution is due to cell death induction. 

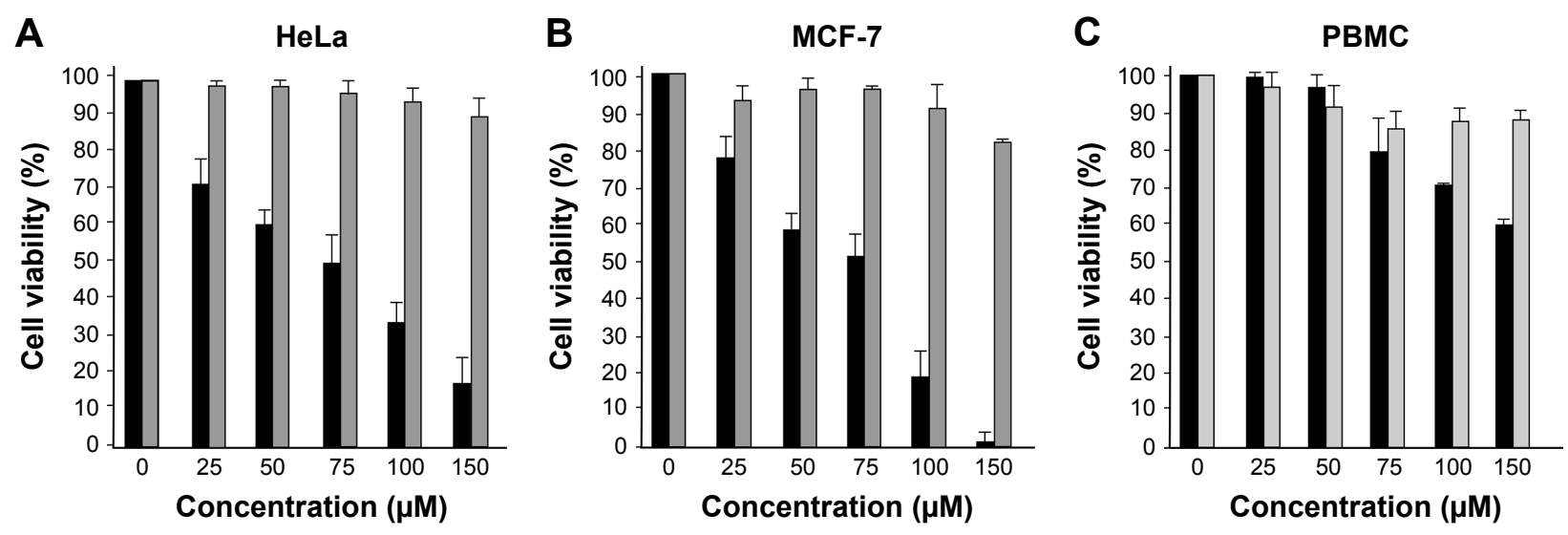

$\square \mathrm{CH}-\mathrm{AuNPs} \quad \square$ SC-AuNPs
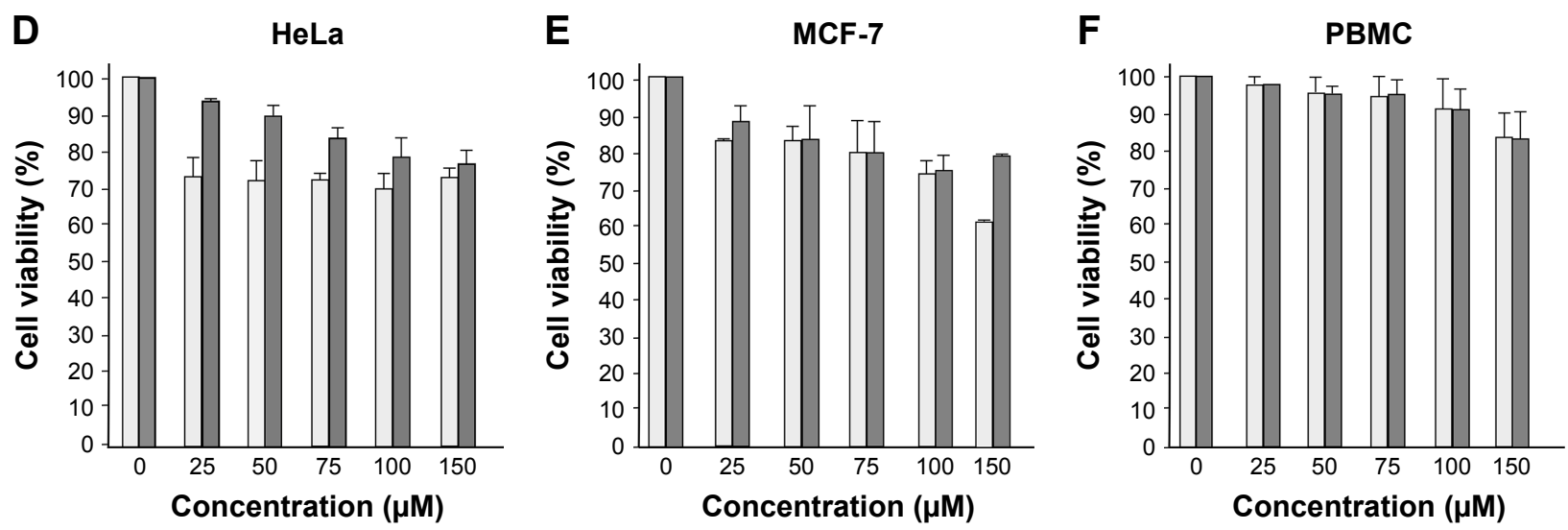

Figure 2 Effect of AuNPs, AuHCl, and chitosan on HeLa, MCF-7, and PBMC cell viability.

Notes: HeLa (A), MCF-7 (B), and PBMC (C) were treated with various concentrations of CH-AuNPs and SC-AuNPs (25, 50, 75, I00, and I50 $\mu$ M). HeLa (D), MCF-7 (E), and PBMC (F) were treated with vehicles (chitosan and $\mathrm{HAuCl}_{4}$ ) at same concentrations as in $(\mathbf{A}-\mathbf{C})$ for 24 hours. Cell viability was measured by MTT assay. The percentages refer to relative cell viability represented as percentage of control (nontreated cell viability=100\%).

Abbreviations: $\mathrm{CH}-\mathrm{AuNPs}$, chitosan gold nanoparticles; PBMC, peripheral blood mononuclear cell; SC-AuNPs, sodium citrate gold nanoparticles.

A
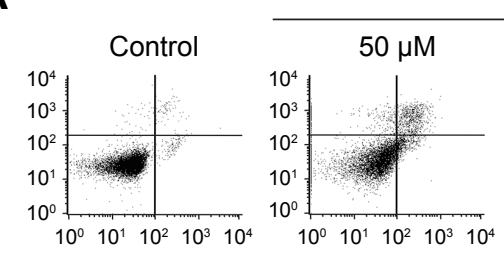

CH-AuNPs
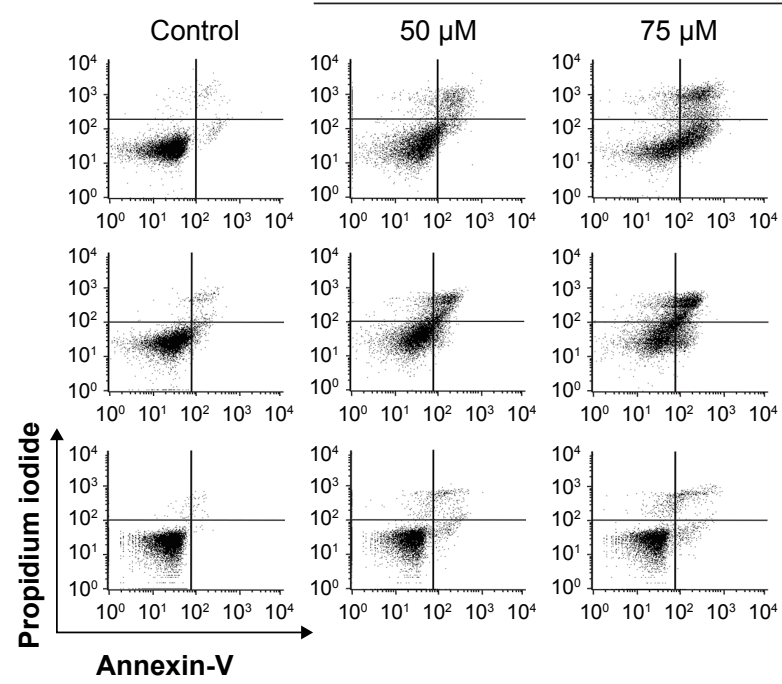

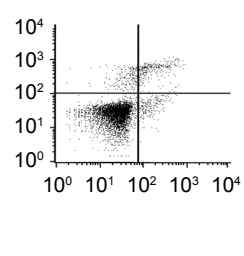

B
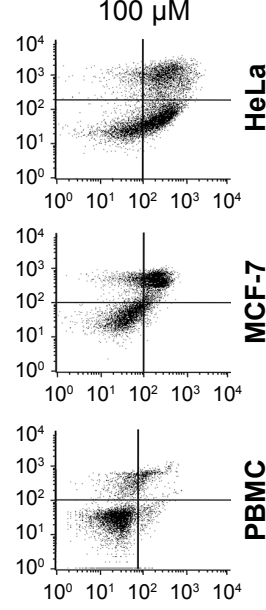

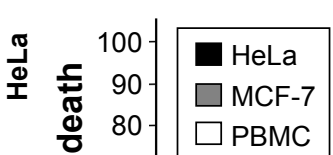

.

บั่

す 50

(1)

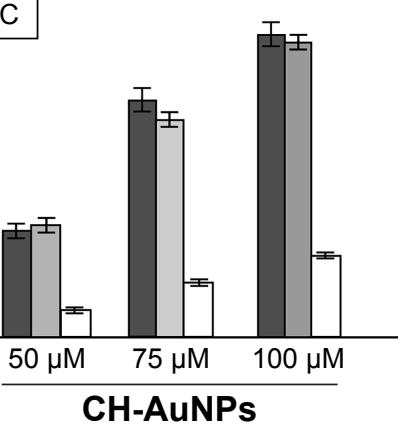

Figure 3 Phosphatidylserine exposure and membrane permeability of HeLa and MCF-7 cells after CH-AuNPs treatment.

Notes: (A) Cell death was measured by flow cytometry through AnnV and PI staining in HeLa and MCF-7 cells treated with different concentrations ( 50 , 75 , and I00 $\mu$ M) of $\mathrm{CH}$-AuNPs for 24 hours. (B) The percentages of cell death refer to AnnV-positive and/or PI-positive staining.

Abbreviations: AnnV, Annexin-V; CH-AuNPs, chitosan gold nanoparticles; PBMC, peripheral blood mononuclear cells; PI, propidium iodide. 

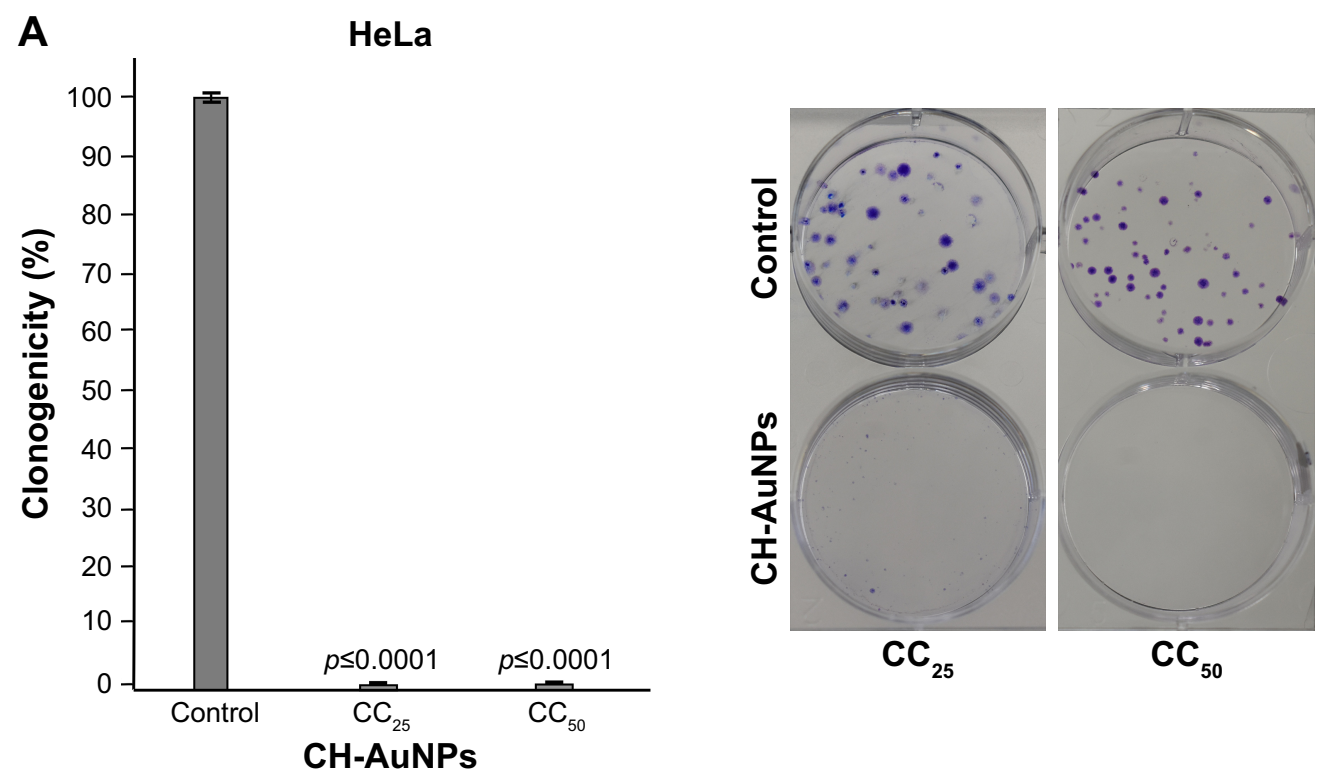

B

MCF-7
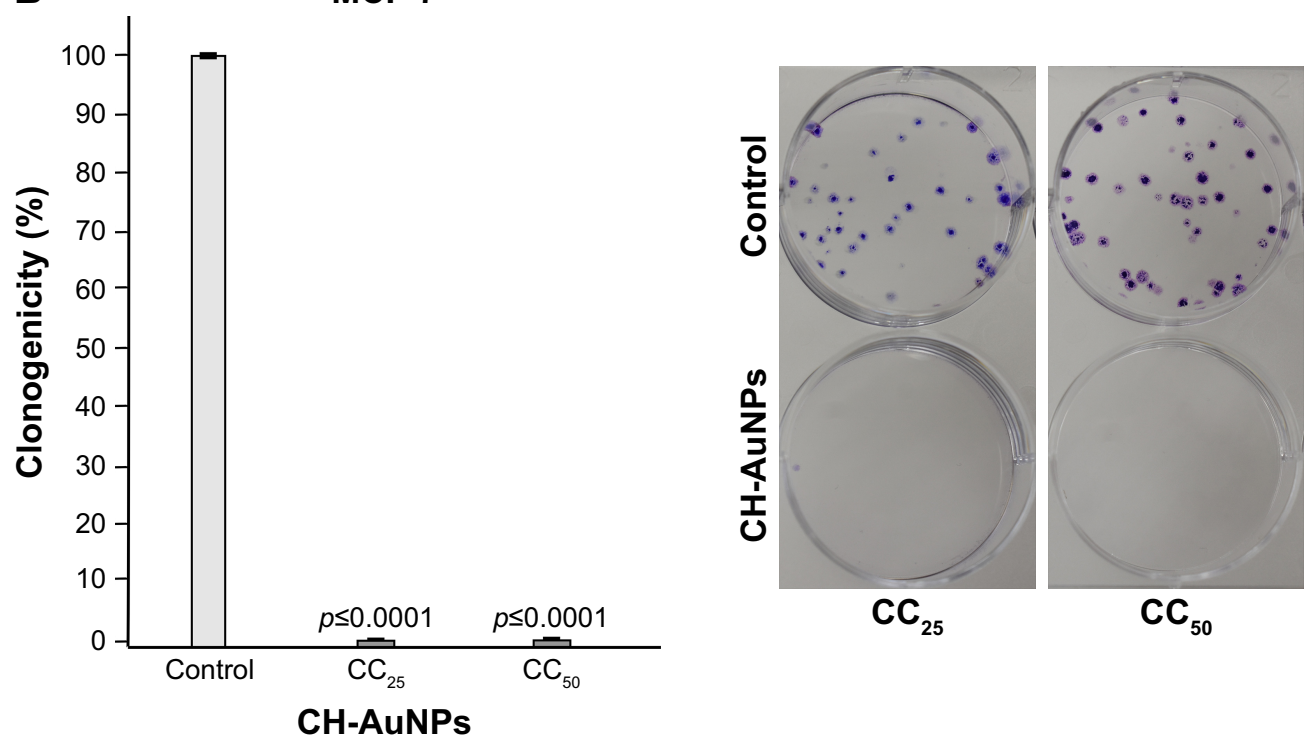

Figure 4 Clonogenic assay shows the long-term effects of $\mathrm{CH}$-AuNPs treatment of HeLa and MCF-7 cells.

Notes: HeLa (A) and MCF-7 (B) cells were treated with $\mathrm{CC}_{25}$ and $\mathrm{CC}_{50}$ of $\mathrm{CH}$-AuNPs for 24 hours, the number of colonies formed on the culture plate 10 days after treatment was expressed as surviving fractions. Data are reported as percentage of colonies compared with untreated control (left). Photograph of petri-dish of a representative experiment is shown (right).

Abbreviations: $\mathrm{CH}-\mathrm{AuNPs}$, chitosan gold nanoparticles; $\mathrm{CC}_{25}$, concentration required to reduce cell viability by $25 \%$; $\mathrm{CC}_{50}$, concentration required to reduce cell viability by $50 \%$.

\section{$\mathrm{CH}-\mathrm{AuNPs}$ do not induce nuclear alterations in HeLa and MCF-7 cells}

Endonucleases can cause DNA fragmentation and nuclear condensation during different types of cell death. ${ }^{27}$ Because some types of AuNPs have been shown to induce DNA fragmentation in diverse cell types, depending on the reducing agent that was used, ${ }^{17,25,28}$ we decided to asses if CH-AuNPs were able to cause DNA fragmentation. To assess DNA degradation, we quantified sub-G1 population of cells treated with $\mathrm{CC}_{25}, \mathrm{CC}_{50}$, or $\mathrm{CC}_{75}$ of $\mathrm{CH}$ AuNPs. DNA degradation was not detected in $\mathrm{HeLa}$ (Figure 6A) or MCF-7 (Figure 6B) cells at the tested concentrations.
To further discard nuclear alterations, we stained HeLa and MCF-7 cells with Hoechst, and nuclear morphology was assessed using a fluorescence microscope. HeLa (Figure 6C) and MCF-7 (Figure 6D) cells treated with CH-AuNPs do not show nuclear condensation after 24 hours of treatment with $\mathrm{CC}_{50}$ (Figure 6).

\section{$\mathrm{CH}-\mathrm{AuNPs}$ induce caspase-dependent cell death in HeLa cells and caspase- independent cell death in MCF-7 cells}

We continued to verify if caspases were the main molecular regulators of this type of cell death. We assessed caspase 
A

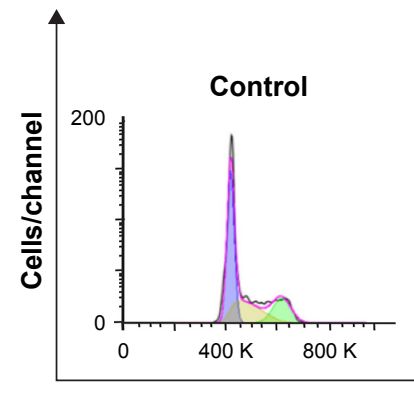

HeLa

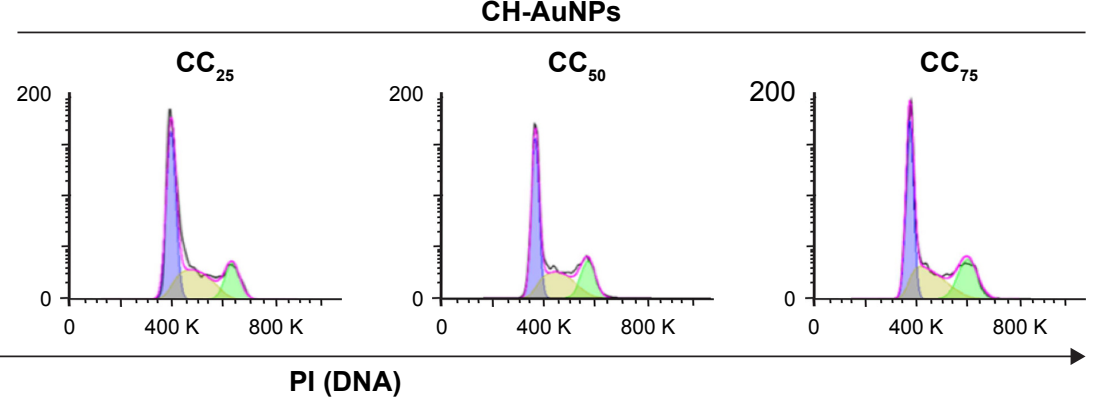

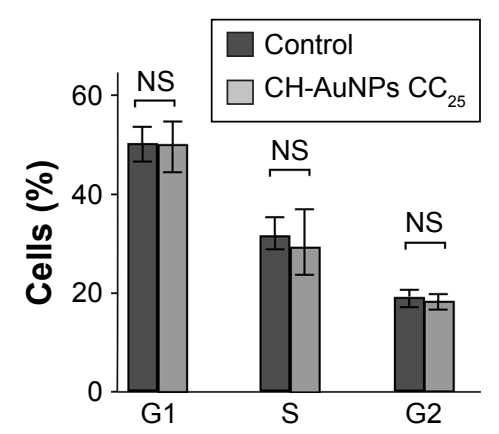
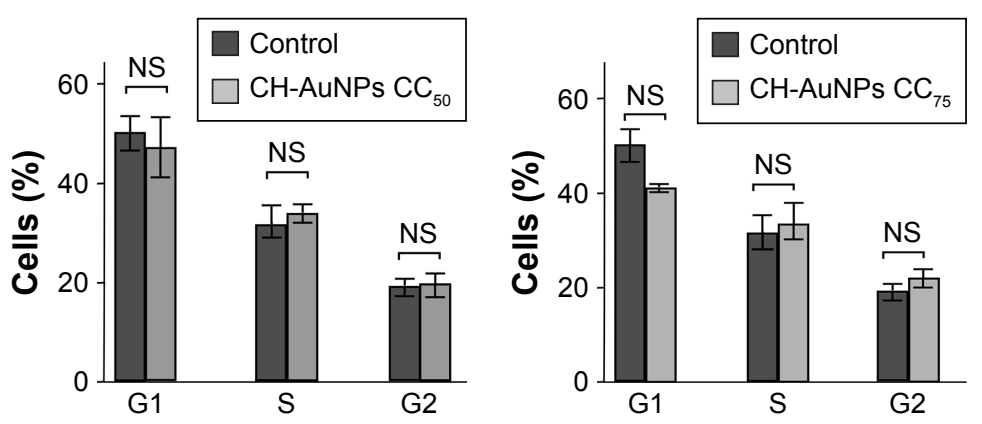

B
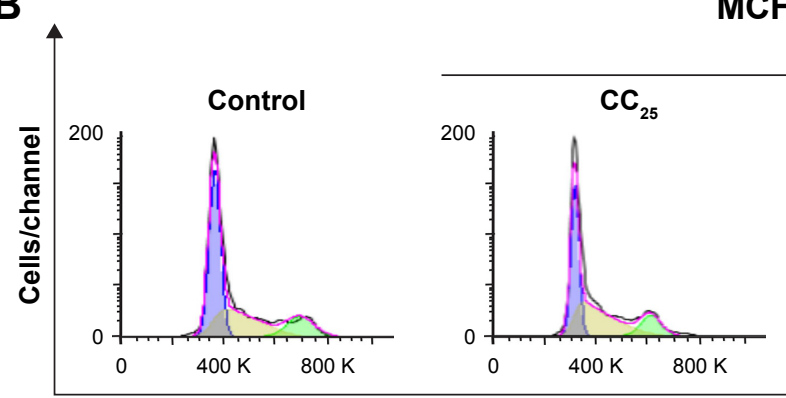

MCF-7

PI (DNA)
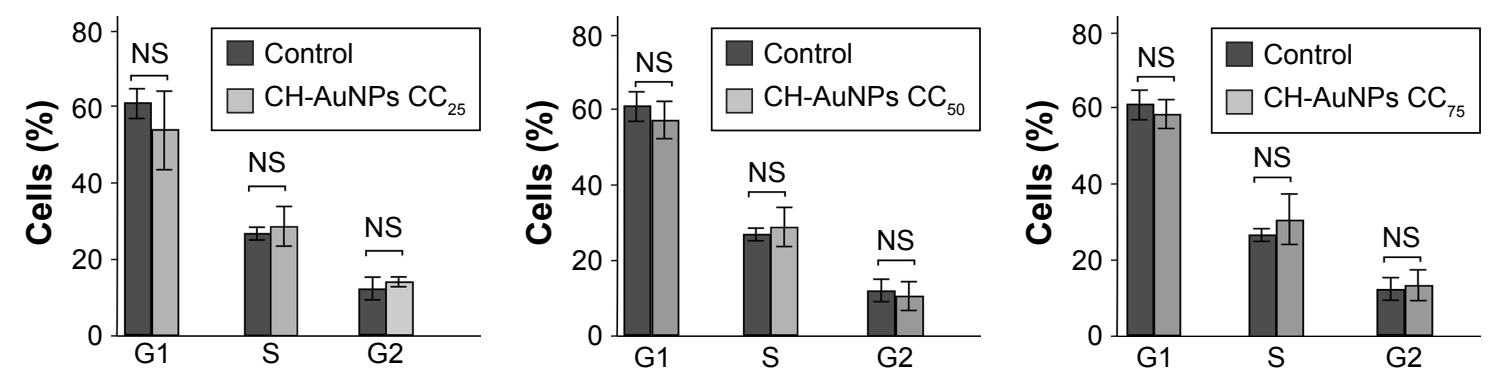

Figure 5 Cell cycle changes after CH-AuNPs treatment of HeLa and MCF-7 cells.

Notes: Representative cell cycle distribution of HeLa (A) and MCF-7 (B) cells treated with $\mathrm{CC}_{25}, \mathrm{CC}_{50}$, and $\mathrm{CC}_{75}$ of $\mathrm{CH}_{-}$-AuNPs for 24 hours. The results were analyzed using Flowjo software and graphed.

Abbreviations: $\mathrm{CH}-\mathrm{AuNPs}$, chitosan gold nanoparticles; $\mathrm{PI}$, propidium iodide; $\mathrm{CC}_{25}$, concentration required to reduce cell viability by $25 \%$; $\mathrm{CC}_{50}$, concentration required to reduce cell viability by $50 \%$; $\mathrm{CC}_{75}$, concentration required to reduce cell viability by $75 \%$; NS, not significant.

activity and, as shown in Figure 7A, CH-AuNPs induce caspase- 3 activation in HeLa cells, whereas MCF-7 cells do not show caspase-3 activity because they are deficient for this caspase ${ }^{29}$ (Figure 7B).

Caspase activity can be detected even if these enzymes are not necessary to induce cell death. To determine if this type of cell death was dependent on caspase activity, we used the pan-caspase inhibitor $\mathrm{QVD}^{30}$ and found that while HeLa cell death was partially inhibited by QVD (Figure 7C), MCF-7 cell death was independent of caspase activation (Figure 7D). In fact, the use of this pan-caspase inhibitor significantly increased the cell death induced by $\mathrm{CH}$-AuNPs 


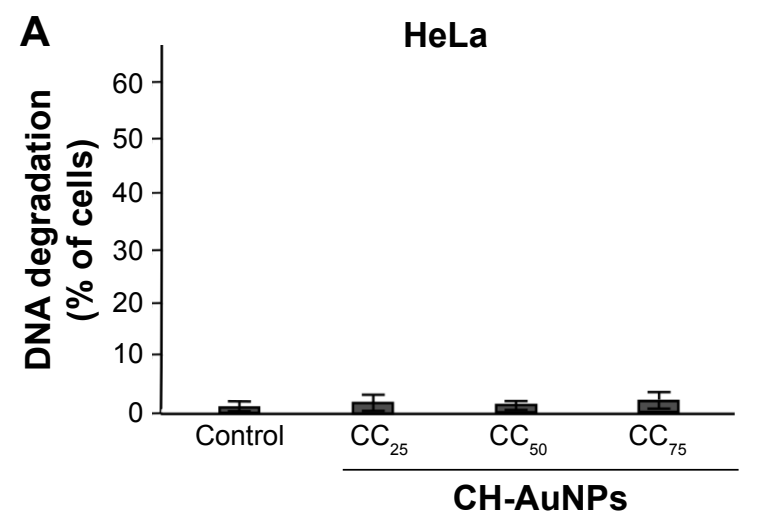

C

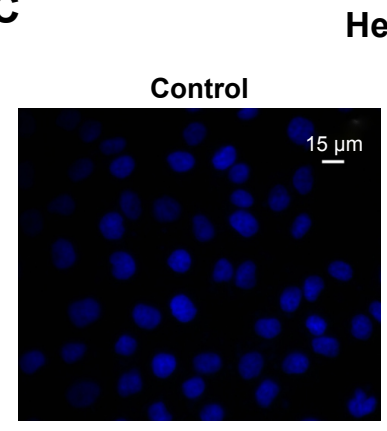

HeLa

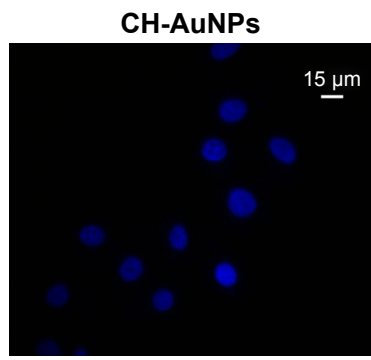

D

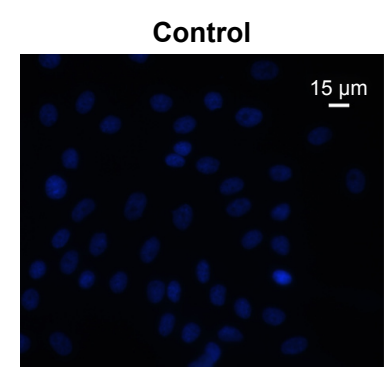

D MCF-7

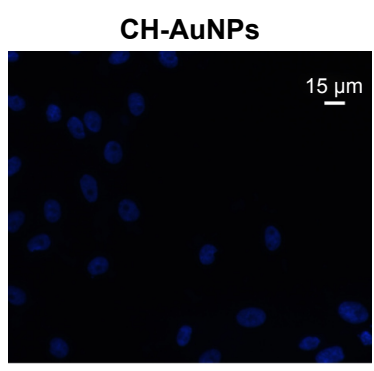

B

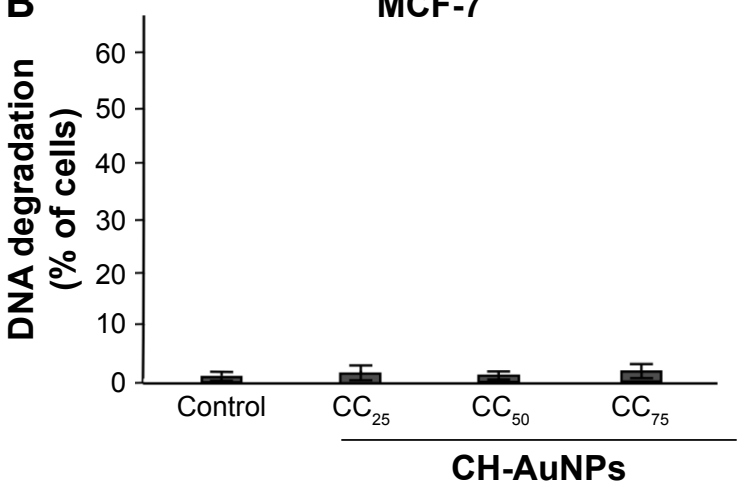

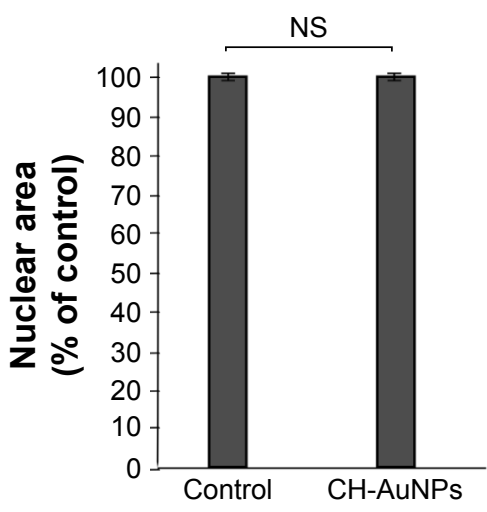

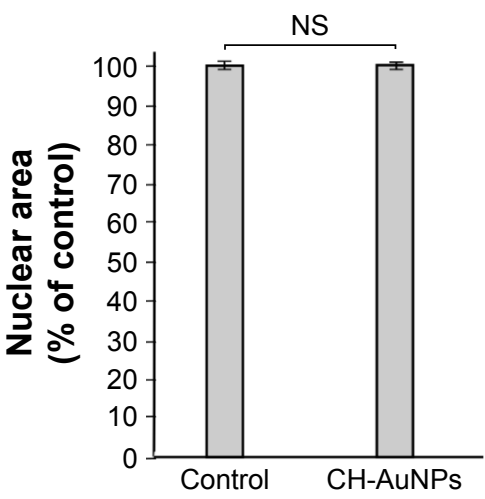

Figure 6 Nuclear alterations induced by CH-AuNPs in HeLa and MCF-7 cells.

Notes: Degradation of DNA in HeLa (A) and MCF-7 (B) cells treated with $\mathrm{CC}_{25}, \mathrm{CC}_{50}$, and $\mathrm{CC}_{75}$ of $\mathrm{CH}-\mathrm{AuNPs}$. Nuclear morphology of HeLa (C) and MCF-7 (D) cells treated with $\mathrm{CC}_{50}$ of $\mathrm{CH}$-AuNPs for 24 hours, stained with Hoechst 33342, and visualized using fluorescence microscopy (OLYMPUS IX70) (40×) (left). The percentages refer to nuclear size measured using Image-J software, and is represented as a \% control (nontreated nuclear size $=100 \%$ ) (right).

Abbreviation: $\mathrm{CH}-\mathrm{AuNPs}$, chitosan gold nanoparticles; $\mathrm{CC}_{25}$, concentration required to reduce cell viability by $25 \%$; $\mathrm{CC}_{50}$, concentration required to reduce cell viability by $50 \% ; \mathrm{CC}_{75}$, concentration required to reduce cell viability by $75 \%$; NS, not significant.

in MCF-7 cells (Figure 7D right). These results show that RCD induced by $\mathrm{CH}$-AuNPs relies differently on caspase activation and that this depends on the cell type.

\section{$\mathrm{CH}-\mathrm{AuNPs}$ induce ROS production and ROS-dependent cell death in HeLa and MCF-7 cells}

AuNPs induced ROS production in several cell types. Because we observed that caspases were not a major feature of cell death induced by $\mathrm{CH}-\mathrm{AuNPs}$, we assessed whether
$\mathrm{CH}-\mathrm{AuNPs}$ were able to induce ROS production in $\mathrm{MCF}-7$ and HeLa cells. As seen in Figure 8, CH-AuNPs treatment induced ROS production in HeLa (Figure 8A) and MCF-7 cells (Figure 8B) as detected by DCFDA staining.

We further analyzed if ROS production was playing a role in cell death. Generation of ROS has been associated with caspase-dependent and caspase-independent cell death. ${ }^{24,31}$ Moreover, different types of nanoparticles induce ROS production, ${ }^{32-34}$ including $\mathrm{CH}$-AuNPs in lung-derived cell lines. ${ }^{35}$ However, the role of ROS production by $\mathrm{CH}$-AuNPs 
A

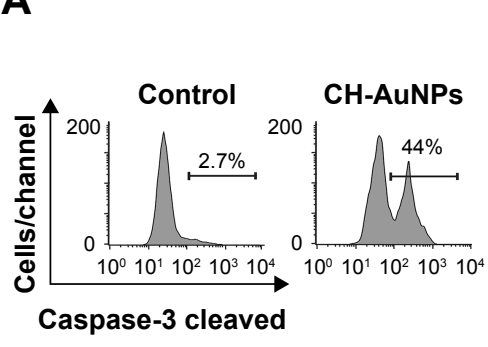

HeLa

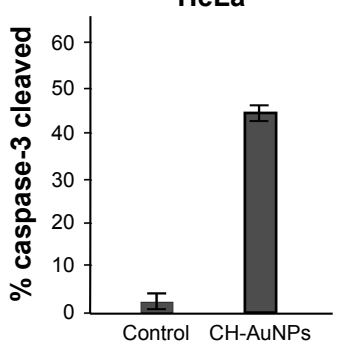

B

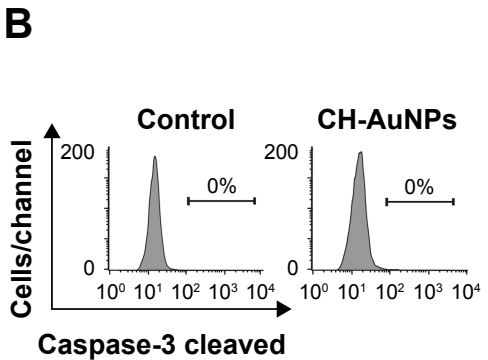

MCF-7

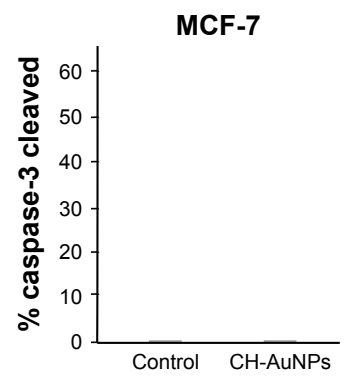

C
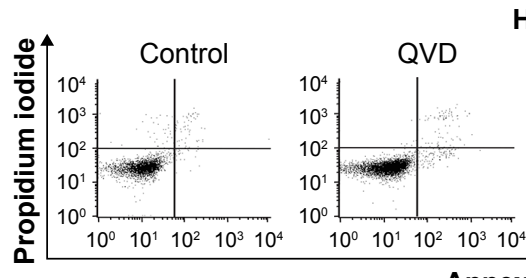

HeLa
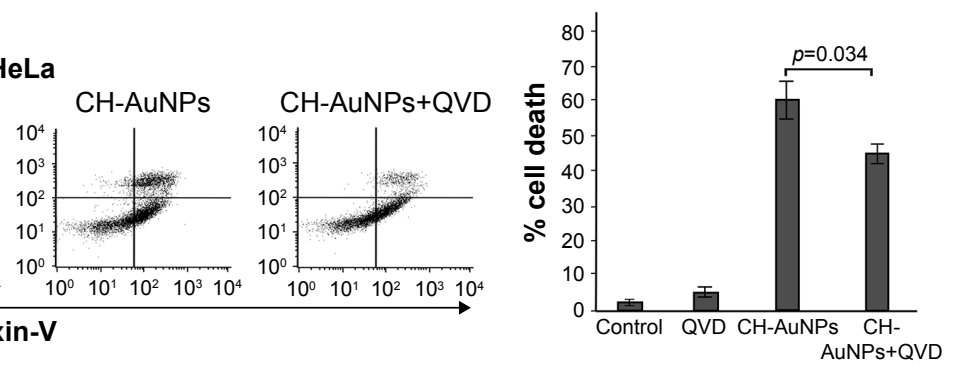

D
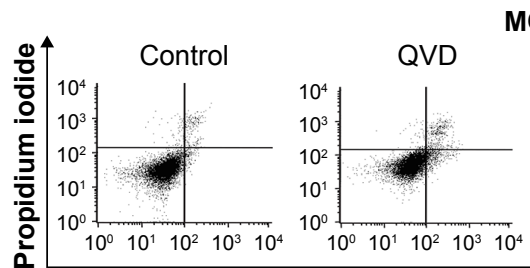

MCF-7
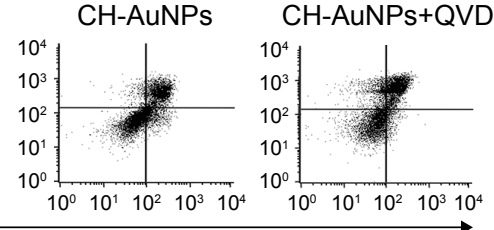

Annexin-V

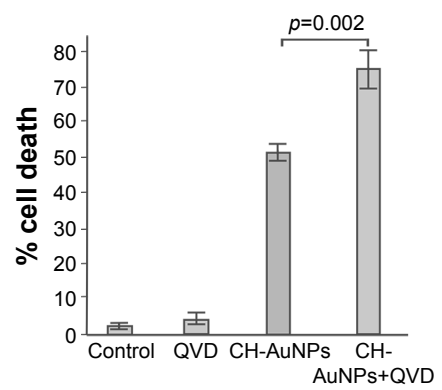

Figure 7 Caspase- 3 activity and effects of pan-caspase inhibition on CH-AuNPs-treated HeLa and MCF-7 cells.

Notes: Caspase-3 activation was measured by flow cytometry in HeLa (A) and MCF-7 (B) cells after treatment with CH-AuNPs for 24 hours (left). Data were then analyzed and graphed (right). Cell viability was determined by flow cytometry in HeLa (C) and MCF-7 (D) cells that were left alone or pretreated with QVD and then treated with $\mathrm{CC}_{50}$ of $\mathrm{CH}$-AuNPs for 24 hours (left). The percentages of the graph bars (right) refer to AnnV-positive and/or Pl-positive staining.

Abbreviations: AnnV, Annexin-V; CH-AuNPs, chitosan gold nanoparticles; PI, propidium iodide; QVD, quinoline-val-asp-difluorophenoxymethyl ketone.

has not been reported. To investigate the role of ROS in CH-AuNPs-RCD, we used the ROS inhibitor NAC, an antioxidant that increases intracellular glutathione levels and possesses thiol-disulfide exchange activity, ${ }^{36}$ and assessed cell death. As shown in Figure 9, NAC was able to inhibit cell death, as observed by the complete reduction of AnnV staining in both HeLa (Figure 9A) and MCF-7 (Figure 9B) cell lines. These results indicate that ROS production is a major and conserved feature of CH-AuNPs; however, $\mathrm{CH}-$ AuNPs did not induce ROS production in PBMCs, even at $100 \mu \mathrm{M}$ (Figure S3).

\section{Discussion}

The cytotoxicity of AuNPs in cancer cells depends on their size, dose, shape, surface chemical radicals, and charge. ${ }^{6}$ We synthesized AuNPs using chitosan and SC and obtained particles of 3-10 nm of diameter with a surface plasmon resonance at $520 \mathrm{~nm}$, which is a characteristic of AuNPs. ${ }^{22}$
Our results showed that $\mathrm{CH}-\mathrm{AuNPs}$ induced cell viability loss in HeLa and MCF-7 cancer cells, while they slightly affected PMBC. SC-AuNPs were not cytotoxic in any of the cell types tested, even though both types of nanoparticles had the same size. Previous studies have shown that the physicochemical properties of nanoparticles are determinant to biological impact; ${ }^{18-20}$ such is the case of their size ${ }^{37}$ and shape..$^{38}$ Small-sized AuNPs (synthesized using different reducing agents) induce low cytotoxicity in dendritic cells ${ }^{39}$ and dermal fibroblasts, ${ }^{40}$ while they are cytotoxic to $\mathrm{HeLa}^{41}$ and A549 28,42 cancer cells. However, the effect of AuNPs also depends on surface charge. It has been demonstrated that positively charged AuNPs are more cytotoxic than negatively charged AuNPs, even when both are of the same size and used in the same cell lines, at the same concentration. ${ }^{13}$ This effect is related to the affinity of the positive charges of the nanoparticles with the negative charge of the cell membrane ${ }^{16,17}$ Additionally, previous studies have reported 
A
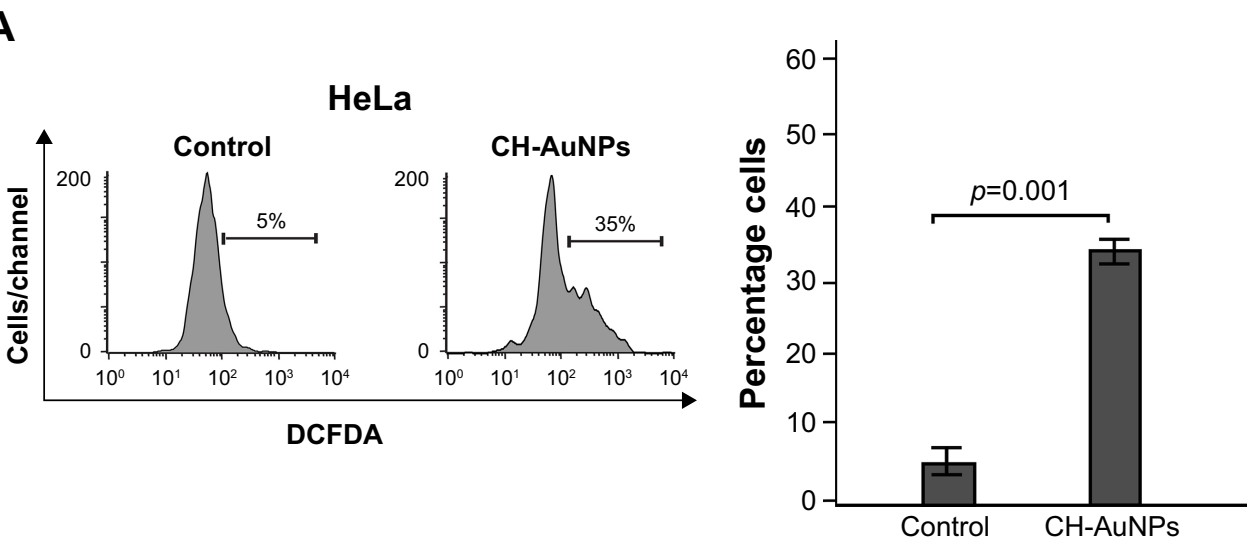

B

MCF-7
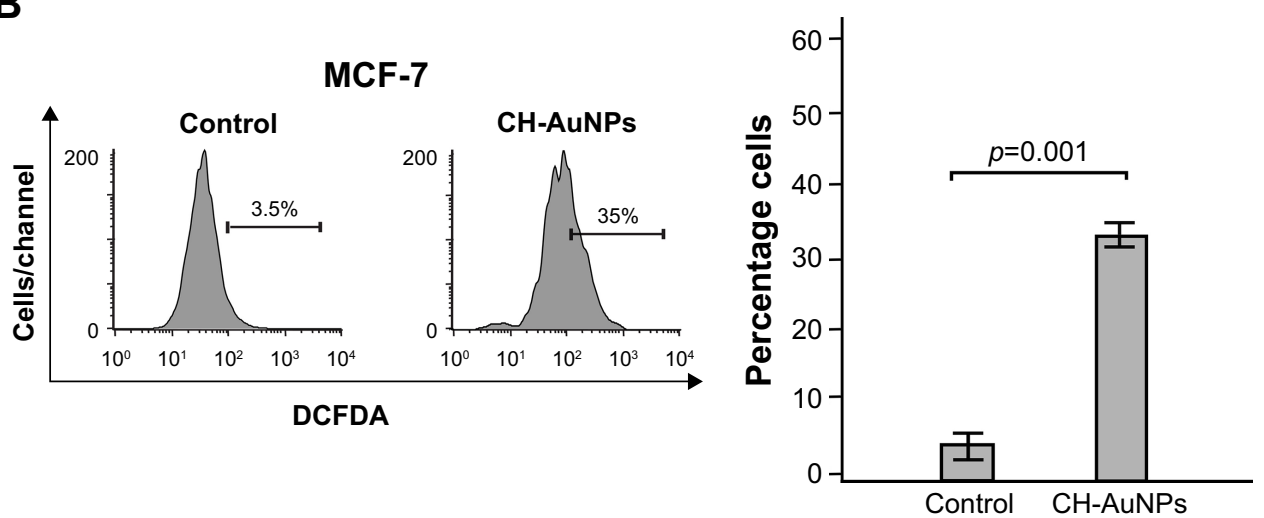

Figure 8 ROS production in HeLa and MCF-7 cells upon treatment with CH-AuNPs.

Notes: ROS levels were measured by flow cytometry through DCFDA staining in HeLa (A) and MCF-7 (B) cells left alone or treated with CC ${ }_{50}$ of $\mathrm{CH}_{-}-\mathrm{AuNPs}_{\mathrm{N}}$ for 24 hours (left). Data were then analyzed and graphed (right).

Abbreviations: $\mathrm{CH}-\mathrm{AuNPs}$, chitosan gold nanoparticles; DCFDA, dichlorodihydrofluorescein diacetate; ROS, reactive oxygen species.

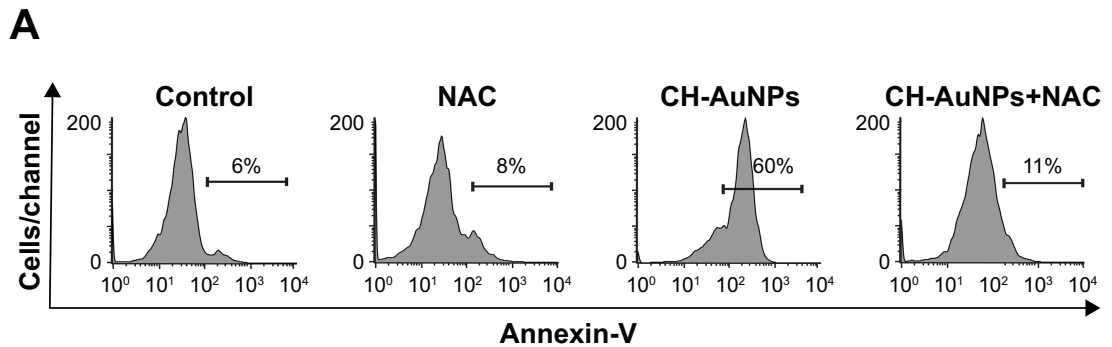

Annexin-V

B

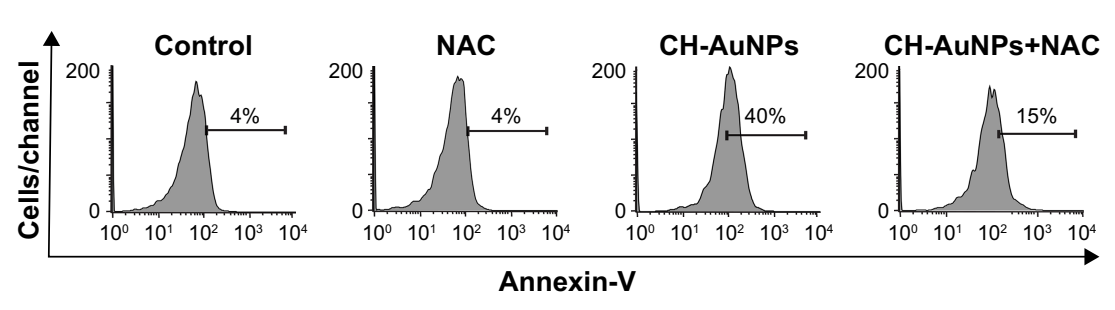

HeLa

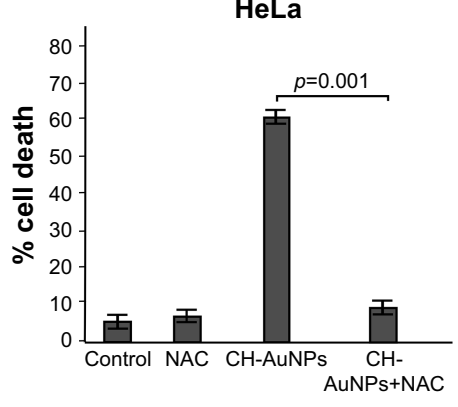

MCF-7

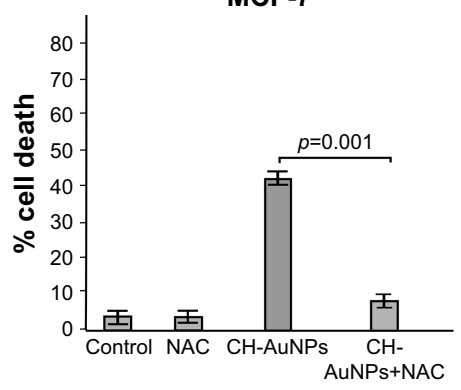

Figure 9 Effect of ROS inhibition upon CH-AuNPs treatment of HeLa and MCF-7 cells.

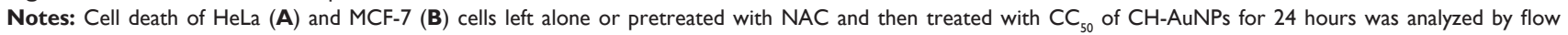
cytometry through AnnV staining (left). The results were analyzed and graphed (right).

Abbreviations: AnnV, Annexin-V; CH-AuNPs, chitosan gold nanoparticles; NAC, N-acetyl-L-cysteine; ROS, reactive oxygen species; $\mathrm{CC}_{50}$, concentration required to reduce cell viability by $50 \%$. 
that the formation of protein corona, a structure of proteins formed between nanoparticles and biological medium, is not dependent on the positive or negative character of the nanoparticle, but that the charge of the nanostructure is responsible for the interactions with specific cellular receptors and therefore the outcome in the target cell. 5,43

Our results showed that nanoparticles effectively induce cell death in HeLa and MCF-7 cell lines. The induction of cell death is one of the main targets in the development of new therapies against cancer. Furthermore, it is known that deregulation of the molecules involved in apoptosis can lead to resistance to first-line chemotherapies. ${ }^{11}$ We also showed that $\mathrm{CH}-\mathrm{AuNPs}$ have selectivity to cancer cells compared to PBMC, at the same concentrations and times. While $\mathrm{CH}$-AuNPs show a dose- and time-dependent cytotoxicity in cancer cells, in PBMCs we observed a dose-dependent effect only, which was maintained after 24 and 48 hours of treatment. Cell-dependent cytotoxicity is a common feature in AuNPs, as it has previously been described in HT29, ${ }^{8}$ MCF-7, ${ }^{28} \mathrm{HeLa},{ }^{32}$ and A45925,42 cells. Another example is the one described by Patra et al who found that AuNPs of the same size $(13 \mathrm{~nm})$ and the same reducing agent (Citrate) are not toxic in Hep2G human liver carcinoma cells and in noncancerous hamster cells, BHK21, but are cytotoxic in A549 human lung carcinoma cells. ${ }^{16}$

Reduction in cell viability can be due to the induction of cell cycle arrest and/or cell death. Here we showed that $\mathrm{CH}-\mathrm{AuNPs}$ induce cell death without affecting cell cycle in the two cancer cell lines tested. This result contrasts with another study where $\mathrm{CH}$-AuNPs were used to treat different lung cancer cell lines, and cell cycle alterations were observed. ${ }^{21}$ Our result resembles another study that used AuNPs with triphenylphosphine monosulfonate and found no alterations in the cell cycle of HeLa cells. ${ }^{32}$ These differences and similarities can be due to the different molecular mechanisms induced by AuNPs, depending on the cell type and the reducing agent used.

Additionally, we observed that a single exposure to $\mathrm{CH}-$ AuNPs for 24 hours inhibits the clonogenic potential of the cells, even though there was no cell cycle arrest, and only $25 \%$ of cells were dead after a 24 -hour treatment. Clonogenic analyses have also been used to predict the metastatic potential of cancer cells. ${ }^{44}$ Thus, our results not only indicate that CH-AuNPs compromise HeLa and MCF-7 cells to clonogenic death, but also that $\mathrm{CH}$-AuNPs could potentially be antimetastatic. However, more studies should be done, as it has also been reported that clonogenic analyses in some cases are not related to the metastatic potential of the cells. ${ }^{45,46}$
Two unexpected aspects of the cell death mechanism induced by $\mathrm{CH}$-AuNPs were the absence of DNA alterations and the selectivity for caspase dependence. The absence of DNA damage in cancer cells exposed to $\mathrm{CH}$-AuNPs contrasts with other studies where DNA fragmentation was observed after treatment with AuNPs. ${ }^{32,47,48}$ However, this was never assessed using chitosan as a reducing agent; thus, these differences can be due to the physicochemical differences of the AuNPs including chitosan. Even though many studies have found that AuNPs and chitosan themselves rely on caspases to induce cell death, ${ }^{13,28,49}$ certain types of AuNPs can induce caspase-independent cell death, ${ }^{48}$ even in HeLa cells, ${ }^{32}$ which contrasts with our results that show caspase-dependent cell death in HeLa cells. This difference may be due to the different agents used to synthesize AuNPs: we used chitosan, whereas Pan et al used triphenylphosphine mono-sulfonat. ${ }^{41}$ Additionally, in our study, we found that even when using the same AuNPs, these differences can be due to the characteristics of each cell line, such as the absence of caspase- 3 in MCF-7 cells. ${ }^{29}$

Despite caspase dependence not being a common feature of CH-AuNP-induced cell death, we found that ROS production was. ROS production has been a recurrent feature in different types of nanoparticle-induced responses, ${ }^{38}$ such as cell death. ${ }^{32,49}$ Previous studies with other types of AuNPs have also demonstrated that ROS production is indispensable for cell death induction. ${ }^{32,41,49}$ Additionally, a previous report stated that $\mathrm{CH}$-AuNPs induced ROS production in lung adenocarcinoma cells. ${ }^{5}$ The importance of ROS production for CH-AuNPs-RCD, however, has not been assessed. The fact that caspase dependence is not conserved in both cell lines and ROS production indicates that ROS could be an upstream event in cell death. It has previously been described that ROS production by nanoparticles can cause mitochondrial alterations leading to other types of RCD, such as the activation of caspases or regulated necrosis. ${ }^{42}$ This finding supports the role of ROS production as a shared feature of $\mathrm{CH}$-AuNPs cytotoxicity, and may be one of the first steps of their RCD pathway, particularly since ROS production was not observed in PBMCs, even at the concentration of $100 \mu \mathrm{M}$. Thus, further analysis should be performed to better understand the mechanism by which $\mathrm{CH}$-AuNPs exert their cytotoxicity.

\section{Conclusion}

Our findings confirm that $\mathrm{CH}-\mathrm{AuNPs}$ have a more potent cytotoxic effect than SC-AuNPs. Additionally, this study 
improves the understanding of the cytotoxicity of $\mathrm{CH}$ AuNPs, as it demonstrates for the first time that they are barely cytotoxic to healthy PBMC, while they induce a concentration-dependent cell death in cancer cells and inhibit their clonogenic potential without inducing DNA damage or cell cycle arrest. We also demonstrated that they induce different cell death modalities in HeLa and MCF-7 cells, but that $\mathrm{CH}-\mathrm{AuNPs}$-induced RCD relies on ROS production. This work opens the way to further characterize this type of cell death that might work in parallel with apoptosis-inducing chemotherapies in functionalized models.

\section{Data availability}

All datasets generated during the current study are available from the corresponding author on reasonable request.

\section{Acknowledgments}

We thank Zugeeissy Samantha de Leon-Chavez for the preliminary data, Martin Gerardo García-Juarez for article revision and overall help, Sergio Galindo (Departamento de Química de la Facultad de Ciencias Biológicas, UANL) for technical help, and Alejandra Arreola for article revision. HYLA thanks CONACyT for scholarship 745665. We thank PAICYT and CONACYT for funding, and the Laboratorio de Inmunología y Virología for the funding and the facilities provided to perform this work.

This work was supported by a research grant from the Consejo Nacional de Ciencia y Tecnología, Ciencia Básica (CB 252017) to C Rodriguez-Padilla, the Proyecto de Apoyo a la Investigación Científica y Tecnológica (PAICYT SA092-15) to AC Martinez-Torres and by the Laboratorio de Inmunología y Virología.

\section{Author contributions}

ACMT, DGZT, HYLA, AAA, CRA, and CRP analyzed and interpreted data. ACMT, DGZT, HYLA, AAA, and CRA performed statistical analysis. DGZT, HYLA, AAA, and CRA synthesized AuNPs. HYLA, AAA, and CRA carried out cell viability, cell cycle and cell death analysis, caspase, microscopy, and ROS assessment. DGZT conceived and supervised the synthesis and characterization of nanoparticles. DGZT, HYLA, and CRP helped to draft the manuscript. AAA and CRA revised the manuscript. ACMT conceived and designed the experiments, supervised work, and wrote the manuscript. All authors approved the final manuscript.

\section{Disclosure}

The authors report no conflicts of interest in this work.

\section{References}

1. Boca S, Potara M, Toderas F, Stephan O, Baldeck P, Astilean S. Uptake and biological effects of chitosan-capped gold nanoparticles on Chinese Hamster Ovary cells. C 31:184-189. Mater Sci Eng. 2011; 31:184-189.

2. Khan J, Pillai B, Das T, Singh Y, Maiti S. Molecular effects of uptake of gold nanoparticles in HeLa cells. Chembiochem. 2007;8:1237-1240.

3. Gonzalez Ballesteros N, Prado Lopez S, Rodriguez Gonzalez JB, Lastra M, Rodríguez-Argüelles MC. Green synthesis of gold nanoparticles using Brown algae Cystoseira baccata: its activity in colon cáncer cells. Colloids Surf B Biointerfaces. 2017;153:190-198.

4. Wang K, Huang Q, Qiu F, Sui M. Non-viral delivery systems for the application in p53 cancer gene therapy. Curr Med Chem. 2015;22(35): 4118-4136.

5. Boyles MSP, Kristl T, Andosch A, et al. Chitosan functionalisation of gold nanoparticles encourages particle uptake and induces cytotoxicity and pro-inflammatory conditions in phagocytic cells, as well as enhancing particle interactions with serum components. J Nanobiotechnology. 2015;13(1):84

6. Regiel-Futyra A, Kus-Liśkiewicz M, Sebastian V, et al. Development of noncytotoxic chitosan-gold nanocomposites as efficient antibacterial materials. Am Chem Soc. 2015;7:1087-9910.

7. Shukla R, Bansal V, Chaudhary M, Basu A, Bhonde RR, Sastry M. Biocompatibility of gold nanoparticles and their endocytotic fate inside the cellular compartment: a microscopic overview. Langmuir. 2005;21: 10644-10654.

8. Alkilany AM, Murphy CJ. Toxicity and cellular uptake of gold nanoparticles: what we have learned so far ? J Nanopart Res. 2010;12: 2313-2333.

9. Torre LA, Bray F, Siegel RL, Ferlay J. Global cancer statistics, 2012 2015;65(2):87-108.

10. Galluzzi L, Bravo-San Pedro JM, Vitale I, et al. Essential versus accessory aspects of cell death: recommendations of the NCCD 2015. Cell Death Differ. 2015;22(1):58-73.

11. Martinez-Torres AC, Quiney C, Attout T, et al. CD47 Agonist peptides induce programmed cell death in refractory chronic lymphocytic leukemia B cells via PLC $\gamma 1$ activation: evidence from mice and humans. PLoS Med. 2015;12(3):e1001796.

12. Villiers C, Freitas H, Couderc R, Villers MB, Marche P. Analysis of the toxicity of gold nanoparticles on the immune system: effect on dendritic cell functions. J Nanoparticle Res. 2010;12:55-60.

13. Goodman CM, Mccusker CD, Yilmaz T, Rotello VM. Toxicity of gold nanoparticles functionalized with cationic and anionic side chains. Bioconjug Chem. 2004;15:897-900.

14. Collado-González M, Fernández Espín V, Montalbán MG, et al. Aggregation behaviour of gold nanoparticles in presence of chitosan. J Nanoparticle Res. 2015;17:268.

15. Cheung RCF, Ng TB, Wong JH, Chan WY. Chitosan: an update on potential biomedical and pharmaceutical applications. Mar Drugs. 2015;13(8):5156-5186.

16. Patra HK, Banerjee S, Chaudhuri U, Lahiri P, Dasgupta K. Cell selective response to gold nanoparticles. Nanomedicine. 2007;3:111-119.

17. Lin J, Zhang H, Chen Z, Zheng Y. Penetration of lipid membranes by gold nanoparticles: insights into cellular. ACS Nano. 2010;4(9): 5421-5429.

18. Arvizo RR, Miranda OR, Thompson MA, et al. Effect of nanoparticle surface charge at the plasma membrane and beyond. Nano Lett. 2010;10(7):2543-2548.

19. Yue ZG, Wei W, Lv PP, et al. Surface charge affects cellular uptake and intracellular trafficking of chitosan-based nanoparticles. Biomacromolecules. 2011;12(7):2440-2446.

20. Jia YP, Ma BY, Wei XW, Qian ZY. The in vitro and in vivo toxicity of gold nanoparticles. Chinese Chem Lett. 2017;28(4):691-702.

21. Choi SY, Jang SH, Park J, et al. Cellular uptake and cytotoxicity of positively charged chitosan gold nanoparticles in human lung adenocarcinoma cells. J Nanoparticle Res. 2012;14:1234. 
22. Amendola V, Pilot R, Frasconi M, Maragò OM, Iatì MA. Surface plasmon resonance in gold nanoparticles: a review. J Phys Condens Matter. 2017;29(20):203002.

23. Oliver Metzig M, Fuchs D, Tagscherer KE, Gröne H-J, Schirmacher P, Roth W. Inhibition of caspases primes colon cancer cells for 5-fluorouracil-induced TNF- $\alpha$-dependent necroptosis driven by RIP1 kinase and NF-кB. Oncogene. 2016;35(26):3399-3409.

24. Kroemer G, Galluzzi L, Vandenabeele P, et al. Classification of cell death: recommendations of the nomenclature committee on cell death 2009. Cell Death Differ. 2009;16(1):3-11.

25. Choi SY, Jeong S, Jang SH, et al. In vitro toxicity of serum proteinadsorbed citrate-reduced gold nanoparticles in human lung adenocarcinoma cells. Toxicol In Vitro. 2012;26(2):229-237.

26. Wimardhani YS, Suniarti DF, Freisleben HJ, Wanandi SI, Siregar NC, Ikeda M. Chitosan exerts anticancer activity through induction of apoptosis and cell cycle arrest in oral cancer cells. J Oral Sci. 2014;56(2):119-126.

27. Leist M. Four deaths and a funeral: from caspases to alternative mechanisms. Nat Rev Mol Cell Biol. 2001;2(8):589-598.

28. Taylor P, Mohan JC, Praveen G, Chennazhi KP, Jayakumar R. Functionalised gold nanoparticles for selective induction of in vitro apoptosis among human cancer cell lines. J Exp Nanosci. 2013;8(1):32-45.

29. Jänicke RU, Sprengart ML, Wati R, et al. Fragmentation and morphological changes caspase-3 is required for DNA fragmentation and associated with apoptosis. J Biol Chem.1998;273(16):9357-9360.

30. Keoni CLI, Brown TL. Inhibition of apoptosis and efficacy of pan caspase inhibitor, Q-VD-OPh, in models of human disease. J Cell Death. 2015;8:1-7.

31. Kroemer G, El-deiry WS, Golstein P, Peter ME, Vaux D. Classification of cell death: recommendations of the nomenclature committee on cell death. Cell Death Differ. 2005;12:1463-1467.

32. Chompoosor A, Saha K, Ghosh PS, et al. The role of surface functionality on acute cytotoxicity, ROS generation and DNA damage by cationic gold nanoparticles. Small. 2010;6(20):2246-2249.

33. Chueh PJ, Liang R-Y, Lee Y-H, Zeng Z-M, Chuang S-M. Differential cytotoxic effects of gold nanoparticles in different mammalian cell lines. J Hazard Mater. 2014;264(2014):303-312.

34. Lim Z-ZJ, Li J-EJ, Ng C-T, Yung L-YL, Bay B-H. Gold nanoparticles in cancer therapy. Acta Pharmacol Sin. 2011;32(8):983-990.

35. Schlinkert P, Casals E, Boyles M, et al. The oxidative potential of differently charged silver and gold nanoparticles on three human lung epithelial cell types. J Nanobiotechnology. 2015;13:1-18.

36. Sun S-Y. N-acetylcysteine, reactive oxygen species and beyond. Cancer Biol Ther. 2011;9(2):109-110.
37. Lundqvist M, Stigler J, Elia G, Lynch I, Cedervall T, Dawson KA. Nanoparticle size and surface properties determine the protein corona with possible implications for biological impacts. Proc Natl Acad Sci US A. 2008;105(38):14265-14270.

38. Wang K, He X, Linthicum W, et al. Carbon nanotubes induced fibrogenesis on nanostructured substrates. Environ Sci Nano. 2017; 4(3):689-699.

39. Villiers CL, Freitas H, Couderc R, Villiers MB, Marche PN. Analysis of the toxicity of gold nano particles on the immune system: effect on dendritic cell functions. J Nanoparticle Res. 2010;12(1):55-60.

40. Pernodet N, Fang X, Sun Y, et al. Adverse effects of citrate/gold nanoparticles on human dermal fibroblasts. Small. 2006;2(6):766-773.

41. Pan Y, Leifert A, Ruau D, et al. Gold nanoparticles of diameter $1.4 \mathrm{~nm}$ trigger necrosis by oxidative stress and mitochondrial damage. Small. 2009;5:2067-2076.

42. Liu M, Gu X, Zhang K, Ding Y. Gold nanoparticles trigger apoptosis and necrosis in lung cancer cells with low intracellular glutathione. $J$ Nanopart Res. 2013;15:1745.

43. Fleischer CC, Payne CK. Nanoparticle-cell interactions: molecular structure of the protein corona and cellular outcomes. Acc Chem Res. 2014;47:2651-2659.

44. Chandrasekaran S, Giang UBT, Xu L, DeLouise LA. In vitro assays for determining the metastatic potential of melanoma cell lines with characterized in vivo invasiveness. Biomed Microdevices. 2016;18(5):89.

45. Nicolson GL, Lembo TM, Welch DR. Growth of rat mammary adenocarcinoma cells in semisolid clonogenic medium not correlated with spontaneous metastatic behavior: heterogeneity in the metastatic, antigenic, enzymatic, and drug sensitivity properties of cells from different sized colonies. Cancer Res. 1988;48(2):399-404.

46. Nomura Y, Tashiro H, Hisamatsu K. In vitro clonogenic growth and metastatic potential of human operable breast cancer in vitro clonogenic growth and metastatic potential of human operable breast. Cancer Res. 1989;49:5288-5293.

47. Krishnaraj C, Muthukumaran P, Ramachandran R, Balakumaran MD. Acalypha indica Linn: biogenic synthesis of silver and gold nanoparticles and their cytotoxic effects against MDA-MB-231, human breast cancer cells. Biotechnol Rep. 2014;4:42-49.

48. Zhang XD, Wu HY, Wu D, et al. Toxicologic effects of gold nanoparticles in vivo by different administration routes. Int J Nanomedicine. 2010;5(1):771-781.

49. Schieber M, Chandel NS. ROS function in redox signaling and oxidative stress. Curr Biol. 2014;24(10):R453-R462. 


\section{Supplementary materials}

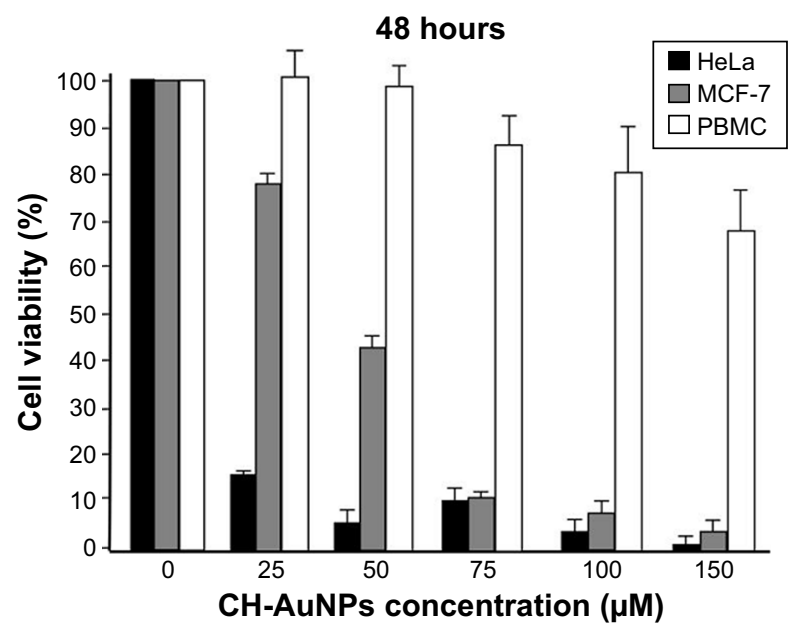

Figure SI Effect of CH-AuNPs on HeLa, MCF-7, and PBMC cell viability after 48 hours of treatment.

Notes: HeLa, MCF-7, and PBMC were treated with various concentrations of CH-AuNPs $(25,50,75,100$, and I50 $\mu$ M) for 48 hours. Cell viability was measured by MTT assay. The percentages refer to relative cell viability represented as percentage of control (nontreated cell viability was normalized to $100 \%$ ).

Abbreviations: $\mathrm{CH}-\mathrm{AuNPs}$, chitosan gold nanoparticles; PBMC, peripheral blood mononuclear cell.

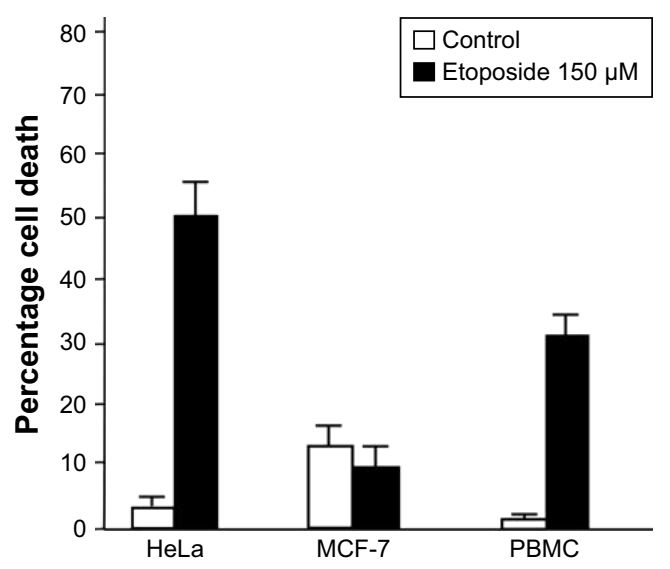

Figure S2 Cell death induced by etoposide in HeLa, MCF-7, and PBMC after 24 hours of treatment.

Notes: Cell death was measured by flow cytometry through AnnV and PI staining in HeLa, MCF-7, and PBMC treated with etoposide for 24 hours. Data were then analyzed and graphed.

Abbreviations: AnnV, Annexin-V; PBMC, peripheral blood mononuclear cell; PI, propidium iodide.

PBMC
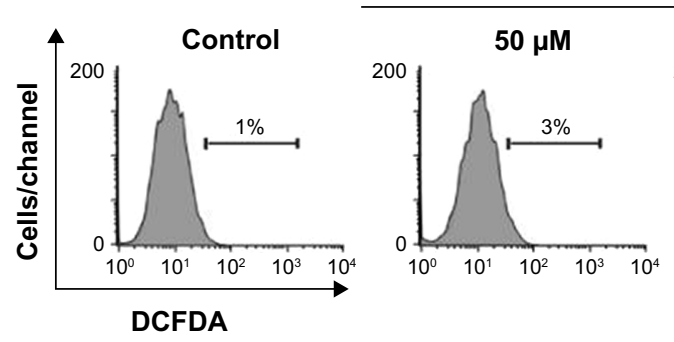

CH-AuNPs

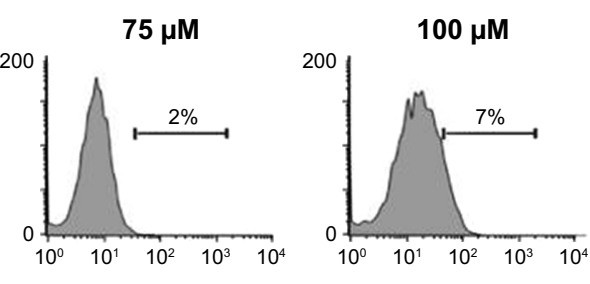

Figure S3 ROS production in PBMC upon treatment with CH-AuNPs.

Notes: ROS levels were measured by flow cytometry through DCFDA staining in PBMC left alone or treated with the indicated concentrations of CH-AuNPs for 24 hours. Representative histograms of ROS production assessed in PBMCs ( $n=3$ donors assessed in triplicate).

Abbreviations: $\mathrm{CH}-\mathrm{AuNPs}$, chitosan gold nanoparticles; DCFDA, dichlorodihydrofluorescein diacetate; PBMC, peripheral blood mononuclear cell; ROS, reactive oxygen species. 


\section{Publish your work in this journal}

The International Journal of Nanomedicine is an international, peerreviewed journal focusing on the application of nanotechnology in diagnostics, therapeutics, and drug delivery systems throughout the biomedical field. This journal is indexed on PubMed Central, MedLine, CAS, SciSearch $\AA$, Current Contents ${ }^{\circledR} /$ Clinical Medicine,
Journal Citation Reports/Science Edition, EMBase, Scopus and the Elsevier Bibliographic databases. The manuscript management system is completely online and includes a very quick and fair peer-review system, which is all easy to use. Visit http://www.dovepress.com/ testimonials.php to read real quotes from published authors.

Submit your manuscript here: http://www.dovepress.com/international-journal-of-nanomedicine-journal 